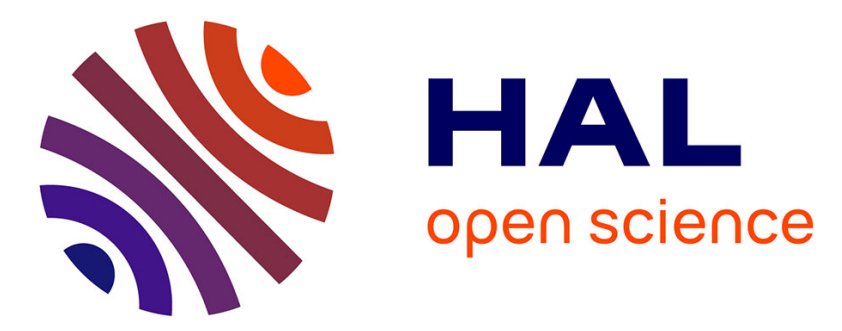

\title{
Vitrification, crystallization behavior and structure of zinc aluminosilicate glasses
}

Laurent Cormier, Ludovic Delbes, Benoit Baptiste, Valérie Montouillout

\section{To cite this version:}

Laurent Cormier, Ludovic Delbes, Benoit Baptiste, Valérie Montouillout. Vitrification, crystallization behavior and structure of zinc aluminosilicate glasses. Journal of Non-Crystalline Solids, 2021, 555, pp.120609. 10.1016/j.jnoncrysol.2020.120609 . hal-03168161

\section{HAL Id: hal-03168161 \\ https://hal.science/hal-03168161}

Submitted on 12 Mar 2021

HAL is a multi-disciplinary open access archive for the deposit and dissemination of scientific research documents, whether they are published or not. The documents may come from teaching and research institutions in France or abroad, or from public or private research centers.
L'archive ouverte pluridisciplinaire HAL, est destinée au dépôt et à la diffusion de documents scientifiques de niveau recherche, publiés ou non, émanant des établissements d'enseignement et de recherche français ou étrangers, des laboratoires publics ou privés. 


\section{Vitrification, crystallization behavior and structure of zinc aluminosilicate glasses}

Laurent Cormier $^{1}$, Ludovic Delbes ${ }^{1}$, Benoit Baptiste ${ }^{1}$, Valérie Montouillout ${ }^{2}$

${ }^{1}$ Sorbonne Université, CNRS, MNHN, IRD, Institut de minéralogie, de physique des matériaux et de cosmochimie (IMPMC), 4 place Jussieu, F-75005 Paris, France

${ }^{2}$ Conditions Extrêmes et Matériaux: Haute Température et Irradiation CEMHTI, CNRS UPR 3079, Univ. D’Orléans 1D Avenue de la Recherche Scientifique, F-45071 Orléans Cedex 2, France

\section{Abstract}

The glass formation, crystallization behavior and structure were investigated in the $\mathrm{ZnO}$ $\mathrm{Al}_{2} \mathrm{O}_{3}-\mathrm{SiO}_{2}$ system. The boundaries of the glass forming region are defined, indicating the absence of glasses along the $\mathrm{ZnO}-\mathrm{SiO}_{2}$ binary and the role of $\mathrm{Al}$ to improve glass formation. The crystallization behavior has been clarified for representative glass compositions showing first crystallization of willemite near the $\mathrm{ZnO}-\mathrm{SiO}_{2}$ binary and a metastable zinc aluminosilicate solid solution for higher $\mathrm{Al}_{2} \mathrm{O}_{3} / \mathrm{SiO}_{2}$ content. Gahnite appears as a second phase and is mainly present near the center of the tectosilicate join. Glass structure was studied using ${ }^{27} \mathrm{Al}$ NMR spectroscopy, neutron and X-ray diffraction and molecular dynamics simulation. Both $\mathrm{Al}$ and $\mathrm{Zn}$ are shown to be distributed between four-fold and five-fold sites. The proportion of ${ }^{[4]} \mathrm{Al}$ is more important near the $\mathrm{ZnAl}_{2} \mathrm{O}_{4}-\mathrm{SiO}_{2}$ join. A remarkable similar behavior is revealed for the glass forming ability and structural properties between $\mathrm{MgO}$ and $\mathrm{ZnO}$ aluminosilicate systems. 


\section{Introduction}

Aluminosilicate glasses are critical compositions in many technological applications (fibers, flat panel displays, chemically strengthened cover glass, waste containments), in geology as equivalent to magmas and are the subject of numerous fundamental research studies. The aluminosilicate glass network is mainly characterized by the degree of Al-Si ordering and the Al speciation. While $\mathrm{Si}^{4+}$ cations are always tetrahedrally-coordinated in ambient conditions, multiple coordination for aluminum has been observed in $\mathrm{CaO}-\mathrm{Al}_{2} \mathrm{O}_{3}-\mathrm{SiO}_{2}$ (CAS) [1][2], $\mathrm{MgO}-$ $\mathrm{Al}_{2} \mathrm{O}_{3}-\mathrm{SiO}_{2}$ (MAS) [3] and $\mathrm{CaO}-\mathrm{MgO}-\mathrm{Al}_{2} \mathrm{O}_{3}-\mathrm{SiO}_{2}$ glasses [4]. This variety of environment around aluminum comes from the lower ability of divalent cations to stabilize Al in four-fold coordination, ${ }^{[4]} \mathrm{Al}$, compared to monovalent cations $\left(\mathrm{Li}^{+}, \mathrm{Na}^{+}\right.$etc). $\mathrm{Zn}^{2+}$ is another divalent cations which is an important component added for ceramic glazes [5][6][7], bioactive glasses [8], optical glasses and glass-ceramics [9][10][11][12][13][11][14]. Addition of zinc to oxide glasses has important beneficial effects: $\mathrm{ZnO}$ is considered as a useful flux in the melting process, lowering the viscosity, and it also improves the chemical durability and mechanical properties [15][16][17][18]. By contrast, its presence in Li or Mg aluminosilicate glasses favors devitrification [15][19]. These two roles of stabilizing glass component or nucleating agent could be due to different coordination sites for $\mathrm{Zn}$. In the former, a tetrahedral configuration implies the presence of low-charge cations to compensate the charge deficit of $\mathrm{ZnO}_{4}$ tetrahedra. As a consequence, less modifier cations are available to depolymerize the network that is stabilized. This can be especially beneficial for borosilicate glasses considered for nuclear waste disposal [20]. The presence of high coordinated $\mathrm{Zn}$ sites is suspected to favor nucleation. However when high-coordinated sites are present, there is predominantly $\mathrm{ZnO}_{4}$ tetrahedra [19][21][22].

The $\mathrm{ZnO}-\mathrm{Al}_{2} \mathrm{O}_{3}-\mathrm{SiO}_{2}$ (ZAS) system is important in many applications of functional glassceramics due to the opportunity to crystallize gahnite $\left(\mathrm{ZnAl}_{2} \mathrm{O}_{4}\right)$ [23][24][14] or willemite $\left(\mathrm{Zn}_{2} \mathrm{SiO}_{4}\right)$ [25][26]. Zincite ( $\left.\mathrm{ZnO}\right)$ can also crystallize in more chemically complex glasses [27]. Those crystals have suitable host matrix for doping with many rare earths and transition elements, providing efficient luminescence [28][29].

The ZAS phase diagram has been studied by Buntig [30] and recently reinvestigated showing significant differences with the previous reported data [31]. Though the glass forming region has been addressed in Buntig's work, a more complete investigation over the ternary diagram is necessary to determine the complete glass forming region. 
The aim of this work is to investigate the glass composition range and the crystallization behavior in the $\mathrm{ZnO}-\mathrm{Al}_{2} \mathrm{O}_{3}-\mathrm{SiO}_{2}$ ternary system as the glass forming region is not ascertained. We analyzed the impact of $\mathrm{ZnO}$ on crystallization properties and compare the results with other divalent cations, in correlation with structural information.

\section{Experimental method}

\subsection{Sample preparation}

The studied compositions (Fig. 1) were prepared by melting dried $\mathrm{Al}_{2} \mathrm{O}_{3}, \mathrm{SiO}_{2}$ and $\mathrm{ZnO}$ oxides. The appropriate quantities of oxides were mixed in an agate mortar in batches of $\sim 5 \mathrm{~g}$. The powder was heated above the melting temperature between $1500-1700^{\circ} \mathrm{C}$ in Pt-alloy crucibles, for a few hours in air with an electrical furnace. The sample was quenched in few seconds by dipping the bottom of the platinum crucible into water. After grinding, a new meltquenching operation was repeated to ensure chemical homogeneity. Several glasses (shown in yellow in Fig. 1) were melted using aerodynamic levitation device using air as flowing gas and $\mathrm{CO}_{2}$ laser as a heating source, yielding glass sphere of about $1 \mathrm{~mm}$ in diameter. The chemical compositions were determined by EPMA (Electron Probe Micro Analysis) using a CAMECA SX100 electron microprobe at the Camparis Center (Sorbonne Université, Paris, France) and reported in Table 1. All glasses are transparent (except ZAS90.05 and ZAS85.07 that contain a large proportion of bubbles) and were observed using optical spectroscopy to determine phase separation and amorphousness was checked using X-ray diffraction. Glasses are labelled according to the nominal chemical composition as ZASx.y where $\mathrm{x}=\mathrm{mol} \% \mathrm{SiO}_{2}, \mathrm{y}=$ $\mathrm{mol} \% \mathrm{Al}_{2} \mathrm{O}_{3}$ and $(100-\mathrm{x}-\mathrm{y})=\mathrm{mol} \% \mathrm{ZnO}$.

The density $(d)$ of the samples was measured using the Archimedes method with acetone as the immersion liquid. From the densities and chemical compositions, the molar volumes $\left(V_{M}\right)$ were calculated as the ratio between the molar mass and the density of the glass. The values for $d$ and $V_{M}$ are reported in Table I.

\subsection{Thermal analysis}

Thermal stability and the phase transformation behavior were studied using Differential Thermal Analysis (DTA) using a LABSYS-evo (SETARAM). Approximately $70 \mathrm{mg}$ of ground 
glass was filled into Pt crucibles in powders with particles sizes between 100-50 $\mu \mathrm{m}$. Heat flow measurements were achieved by scanning from room temperature to $1200^{\circ} \mathrm{C}$ with a $10^{\circ} \mathrm{C} / \mathrm{min}$ heating rate, under an argon flow of 1.5 bar pressure. Glass transition temperatures were measured at the minimum of the derivative of the heat flow versus temperature. Crystallization temperatures were determined at the peak maximum of the exothermic peak.

\section{Table 1}

Chemical compositions determined by EPMA, densities and molar volumes of the ZAS glasses.

\begin{tabular}{|c|c|c|c|c|c|}
\hline \multirow[t]{2}{*}{ Sample } & \multicolumn{3}{|c|}{ Chemical composition (mol\%) } & \multirow[t]{2}{*}{$d\left(\mathrm{~g} \mathrm{~cm}^{-3}\right)$} & \multirow[t]{2}{*}{$V_{M}\left(\mathrm{~cm}^{3} \mathrm{~mol}^{-1}\right)$} \\
\hline & $\mathrm{ZnO}$ & $\mathbf{A l}_{2} \mathbf{O}_{3}$ & $\mathrm{SiO}_{2}$ & & \\
\hline ZAS90.05 & 5.36 & 6.51 & 88.13 & $-{ }^{a}$ & - \\
\hline ZAS85.07 & 6.91 & 8.25 & 84.84 & $-{ }^{a}$ & - \\
\hline ZAS75.12 & 12.01 & 13.29 & 74.70 & $2.59 \pm 0.02$ & 26.4 \\
\hline ZAS72.07 & 17.61 & 11.16 & 71.23 & $2.73 \pm 0.02$ & 25.1 \\
\hline ZAS68.16 & 15.24 & 16.19 & 68.57 & $2.71 \pm 0.01$ & 25.9 \\
\hline ZAS68.11 & 21.01 & 11.60 & 67.39 & $2.91 \pm 0.01$ & 23.8 \\
\hline ZAS60.10 & 28.41 & 10.32 & 61.27 & $3.11 \pm 0.01$ & 22.6 \\
\hline ZAS60.20 & 21.21 & 22.01 & 56.78 & $2.57 \pm 0.01$ & 28.7 \\
\hline ZAS60.25 & 13.61 & 25.53 & 60.86 & $2.74 \pm 0.01$ & 26.9 \\
\hline ZAS50.10 & 39.60 & 10.80 & 49.60 & $3.35 \pm 0.01$ & 21.8 \\
\hline ZAS50.20 & 27.68 & 20.26 & 52.06 & $3.03 \pm 0.02$ & 24.6 \\
\hline ZAS50.25 & 23.35 & 25.29 & 51.36 & $2.99 \pm 0.01$ & 25.1 \\
\hline $\begin{array}{l}\text { ZAS50.30 } \\
\text { (levitation) }\end{array}$ & 20 & 30 & 50 & & \\
\hline $\begin{array}{l}\text { ZAS50.35 } \\
\text { (levitation) }\end{array}$ & 15 & 35 & 50 & & \\
\hline $\begin{array}{l}\text { ZAS50.40 } \\
\text { (levitation) }\end{array}$ & 10 & 40 & 50 & & \\
\hline ZAS45.27 & 26.75 & 27.81 & 45.44 & $3.06 \pm 0.01$ & 25.3 \\
\hline ZAS42.29 & 27.74 & 29.06 & 43.20 & $3.09 \pm 0.01$ & 25.3 \\
\hline $\begin{array}{l}\text { ZAS40.30 } \\
\text { (levitation) }\end{array}$ & 30 & 30 & 40 & & \\
\hline ZAS40.10 & 49.17 & 9.86 & 40.97 & $3.70 \pm 0.01$ & 20.2 \\
\hline ZAS40.15 & 41.33 & 15.12 & 43.55 & $3.45 \pm 0.02$ & 21.8 \\
\hline ZAS35.10 & 54.20 & 10.98 & 34.82 & $3.90 \pm 0.01$ & 19.6 \\
\hline
\end{tabular}

a This sample contains a large proportion of bubbles that prevents an accurate measurement of its density. 
${ }^{\mathrm{b}}$ Glass composition was not determined for these samples and only the nominal composition is given.

\subsection{High resolution solid state NMR spectroscopy}

The ${ }^{27} \mathrm{Al}$ high-resolution NMR experiments have been conducted at $20.0 \mathrm{~T}(850 \mathrm{MHz})$ on a Bruker AVANCE spectrometer equipped with high-speed MAS probe head (spinning rates $30 \mathrm{kHz}$, aluminum free zirconia rotors of $2.5 \mathrm{~mm}$ diameter). 1D MAS spectra have been acquired after a single short pulse $(\pi / 10)$ ensuring a quantitative excitation and quantification of ${ }^{27} \mathrm{Al}$ central transition. Chemical shifts were referenced relative to $\mathrm{Al}\left(\mathrm{NO}_{3}\right)_{3} 1 \mathrm{M}$ solution. The spectra have been simulated using DMfit software [32].

\subsection{Neutron and X-ray diffraction}

The neutron diffraction data were performed using the 7C2 Diffractometer at LLB (Saclay, France) [33]. Glass powders ( 4g) were loaded into a cylindrical vanadium can of $6 \mathrm{~mm}$ in diameter. The diffracted intensities are recorded with an incoming wavelength of $\lambda=0.592 \AA$, giving access to a $Q$-range of $0.7-21 \AA^{-1}(Q=4 \pi \sin \theta / \lambda$, with $\theta$ the scattering angle $)$. Standard data corrections (detector efficiency, background and container scattering, absorption, multiple scattering, inelastic effects and normalization from a vanadium standard) were applied to obtain the structure factor, $S^{N}(Q)$.

The X-ray diffraction data were collected using a laboratory Panalytical Empyrean (Amelo, Netherlands) diffractometer equipped with $\mathrm{Ag} \mathrm{K} \alpha$ radiation $(0.5609 \AA)$, operating at $36 \mathrm{~mA}$ and $50 \mathrm{kV}$, and a scintillation detector. Powder samples are placed in a kapton capillary, $1 \mathrm{~mm}$ diameter. Data were measured in a Q-range of 0.3-21 $\AA^{-1}$. The same acquisition strategy was used for measuring the contribution of the empty kapton capillary. The total structure factors for X-ray diffraction $S^{R X}(Q)$ were extracted with the PDFgetx3 program [34].

High-temperature X-ray diffraction (HT-XRD) patterns were collected using a PANalytical X'Pert PRO (Amelo, Netherlands) diffractometer with Co $\mathrm{K} \alpha$ radiation operating at $40 \mathrm{kV} / 40 \mathrm{~mA}$. In order to identify the crystal phases formed upon temperature, measurements were carried out in situ using an Anton Paar HTK 1200 furnace (Graz, Austria). Scan data was collected by a X-Celerator detector over an angular range $10^{\circ} \leq 2 \theta \leq 90^{\circ}$ at room temperature, $750{ }^{\circ} \mathrm{C}, 850^{\circ} \mathrm{C}, 950^{\circ} \mathrm{C}$ and $1050^{\circ} \mathrm{C}$, using an acquisition time of $45 \mathrm{~min}$ and an average heating rate of $10^{\circ} \mathrm{C} / \mathrm{min}$ (including ramps and measurements). Selected samples were prepared 
as coarsely crushed powders to limit surface crystallization. X-ray diffractograms analysis was performed using X-Pert High Score Plus (Panalytical) software to identify the crystalline phases from their peak locations and intensities using ICDD patterns.

\subsection{Molecular Dynamics Simulations}

The DL_Poly code [35] was used to perform Molecular Dynamics (MD) simulations on a cubic box containing 4225 atoms with the composition of ZAS50.25. The density was fixed to the experimental one. Morse type interaction potentials between atomic pairs were described in a previous publication [36]. The system was first equilibrated at $5000 \mathrm{~K}$ in the NVE ensemble for $1 \mathrm{~ns}$ with an integration time step of $1 \mathrm{fs}$ and then quenched to room temperature in a NVT ensemble using a Berendsen thermostat and a quenching rate of $4.10^{12} \mathrm{~K} \mathrm{~s}^{-1}$.

\section{Results}

\subsection{Glass forming domain}

Figure 1 presents the ZAS ternary diagram with the glass forming region (in red) determined in this study. This domain corresponds to samples being completely amorphous with no macroscopic phase separation or partial crystallization (phase separation has not been probed by Transmission Electron Microscopy that could provide evidences of nanoscopic heterogeneities [37][38]). Some samples (grey squares) are mixed crystalline and glassy part but the glassy part was not analyzed and could deviate significantly from the nominal composition. The boundaries are not exactly defined since the glass formation depends on many factors, among which the quenching rate or the use of a crucible or not. Quenching by dipping the bottom of the Pt crucibles into water allows the synthesis of glasses marked with red squares. Using aerodynamic levitation with laser heating, it is possible to extend the vitrification domain since crystallization from the melt/crucible interface is abolished. Using this technique, glasses in the peraluminous region can be synthesized (yellow squares in figure 1) but have not been further investigated in the present work due to the low quantity. Though volatilization can result from the levitation process, past studies on similar aluminosilicate glasses have shown a limited effect on the composition [2]. We then decided to include these points in the glass forming region. 
Though Buntig reported glasses with high $\mathrm{ZnO}$ content and poor $\mathrm{SiO}_{2}$ content [30], we were not able to reproduce this result with a furnace having a maximum temperature of $1700^{\circ} \mathrm{C}$ or by laser heating. In this latter case, an important volatilization is observed. Zn-rich glasses, partly crystallized (grey points in figure 1), can however be obtained.

We were not able to synthesize glasses along the $\mathrm{ZnO}-\mathrm{SiO}_{2}$ binary, even using aerodynamic levitation. Samples along the binary result in a phase separated glass containing a ZnO-rich glass matrix and $\mathrm{SiO}_{2}$-rich droplets according to a previous investigation [9]. Only willemite $\left(\mathrm{Zn}_{2} \mathrm{SiO}_{4}\right), \mathrm{ZnO}$ and $\mathrm{SiO}_{2}$ crystals can be formed in this binary and a large immiscibility gap forming above $1400^{\circ} \mathrm{C}$ exists for $\mathrm{SiO}_{2}>50 \mathrm{~mol} \%$ [31]. It is necessary to add $10 \mathrm{~mol} \% \mathrm{Al}_{2} \mathrm{O}_{3}$ to improve the glass stability [9]. This is consistent with aluminum playing a network forming role improving glass formation.

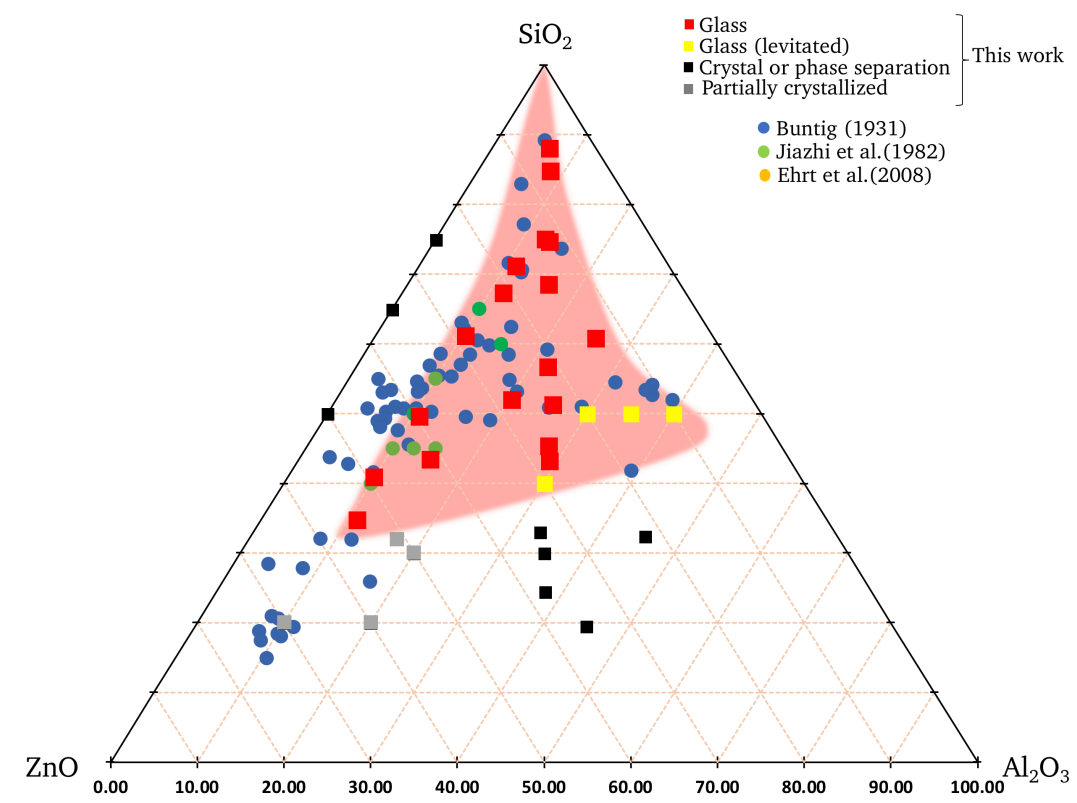

Fig. 1. Glass formation (in red) in the $\mathrm{ZnO}-\mathrm{Al}_{2} \mathrm{O}_{3}-\mathrm{SiO}_{2}$ ternary system. Glasses found in previous investigations are also shown [30][9][39].

\subsection{Density}

The composition evolution of density and molar volume is given in Fig. 2 as a function of the $\mathrm{ZnO}$ content. An almost linear trend is observed. As $\mathrm{ZnO}$ content increases, the density increases and the molar volume decreases. The low molar volume at high $\mathrm{ZnO}$ content indicates a denser packing of the glass structure. This suggests that $\mathrm{Zn}^{2+}$ cations are easily inserted into the free volume of the aluminosilicate network. A MD study indicates that the Si-O-Zn angle 
decreases with $\mathrm{ZnO}$ addition, reducing the volume between $\mathrm{Zn}$ and $\mathrm{Si}$ units [40]. Geometrical and structural changes allow for the more compact network structure at high $\mathrm{ZnO}$ content.

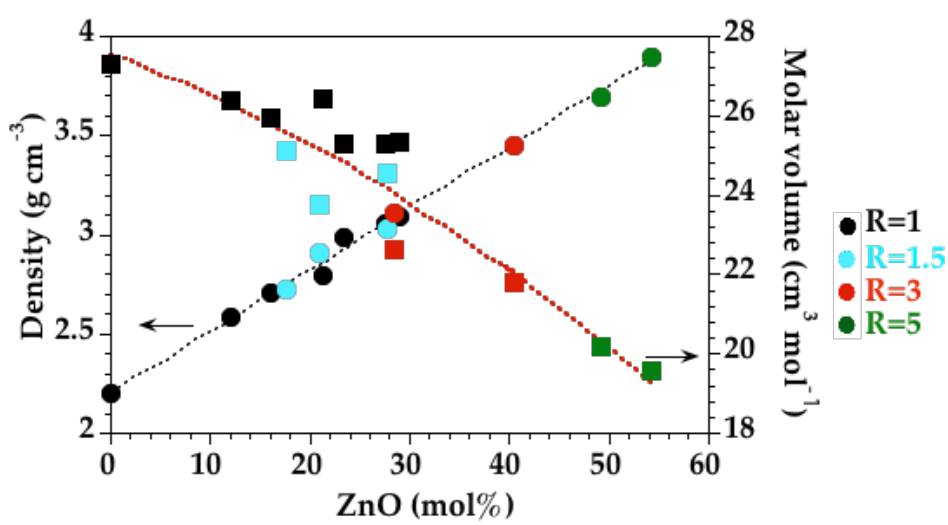

Fig. 2. Density and molar volume of ZAS glasses (Table 1) as a function of the $\mathrm{ZnO}$ content. $\mathrm{R}=\mathrm{ZnO} / \mathrm{Al}_{2} \mathrm{O}_{3}$.

\subsection{Crystallization behavior}

DTA and HT-XRD were used to determine the crystallization behavior of some selected glass compositions (Table 1). Typical DTA curves are shown in Fig. 3 and the glass transition temperatures ( $\mathrm{Tg}$ ) and crystallization temperatures $(\mathrm{Tc})$ are reported in Table 2. It can be seen that $\mathrm{Tg}$ values decrease as the $\mathrm{ZnO}$ content increases. These values are also lower compared to other aluminosilicate glasses containing divalent cations [41][42][43].

Several exothermic events can be observed in the DSC curves, corresponding to the formation of different crystalline phases. At high silica content, a single broad exothermic peak is observed at $930-950^{\circ} \mathrm{C}$. With the addition of $\mathrm{ZnO}$ (ZAS68.11), an additional sharp peak at $\sim 1045^{\circ} \mathrm{C}$ appears. The crystallization peaks are shifted towards lower temperature as the $\mathrm{SiO}_{2}$ or the $\mathrm{ZnO}$ content decreases. When $\mathrm{ZnO}$ content increases, multiple peaks and shoulders indicate the formation of several crystallite à ne phases. The crystallization appears at the lowest temperatures for the glasses with high $\mathrm{ZnO}$ content. 


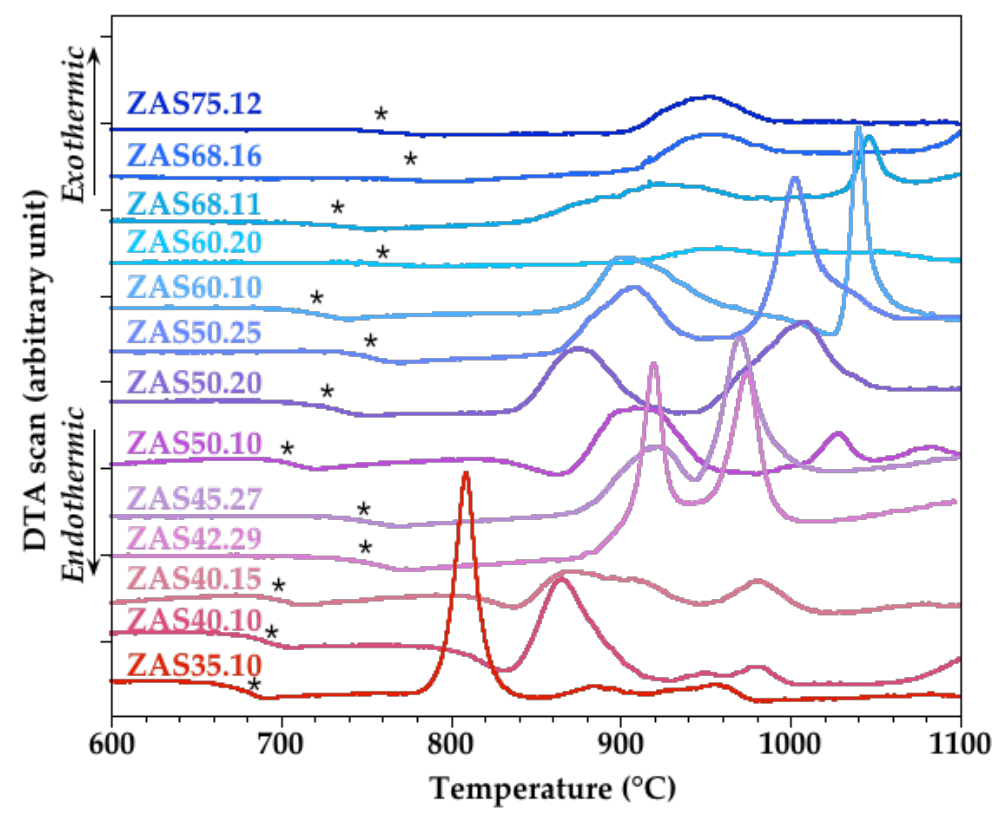

Fig. 3. DTA curves of the ZAS glasses. The asterisks indicate the glass transition.

\section{Table 2}

Characteristic temperatures $\left( \pm 1^{\circ} \mathrm{C}\right)$ determined by DTA measurements.

\begin{tabular}{|l|l|l|l|l|}
\hline Sample & $\mathbf{T g}\left({ }^{\circ} \mathbf{C}\right)$ & $\mathbf{T c 1}\left({ }^{\circ} \mathbf{C}\right)$ & $\mathbf{T c 2}\left({ }^{\circ} \mathbf{C}\right)$ & Tc3 $\left({ }^{\circ} \mathbf{C}\right)$ \\
\hline ZAS75.12 & 760 & 950 & & \\
\hline ZAS68.16 & 777 & 954 & & \\
\hline ZAS68.11 & 731 & 932 & 1046 & \\
\hline ZAS60.10 & 719 & 906 & 1040 & \\
\hline ZAS60.20 & 759 & 962 & 1016 & 1050 \\
\hline ZAS60.25 & 792 & 934 & 966 & \\
\hline ZAS50.25 & 752 & 907 & 1003 & \\
\hline ZAS50.20 & 728 & 876 & 1007 & \\
\hline ZAS50.10 & 704 & 910 & 1028 & 1082 \\
\hline ZAS45.27 & 747 & 922 & 970 & \\
\hline ZAS42.29 & 748 & 919 & 974 & \\
\hline ZAS40.15 & 698 & 870 & 981 & \\
\hline ZAS40.10 & 688 & 866 & 949 & 981 \\
\hline ZAS35.10 & 676 & 809 & 884 & 957 \\
\hline
\end{tabular}

In order to determine the nature of the forming phases, HT-XRD measurements have been recorded from $750^{\circ} \mathrm{C}$ up to $1050^{\circ} \mathrm{C}$, with $50^{\circ} \mathrm{C}$ step and an average heating rate of $10^{\circ} \mathrm{C} / \mathrm{min}$. The main crystalline phases and the temperature treatments are reported in Table 3. Except the sample ZAS35.10 that presents willemite peaks at $750^{\circ} \mathrm{C}$, all the other samples remain 
amorphous until $850^{\circ} \mathrm{C}$.

The first phase appearing is usually a metastable zinc aluminosilicate solid solution (ZASs.s.). ZAS s.s. is a stuffed derivative of $\beta$-quartz [44], in which $\mathrm{Si}^{4+}$ is partially replaced by $\mathrm{Al}^{3+}$ and small radius cations $\left(\mathrm{Li}^{+}, \mathrm{Mg}^{2+}, \mathrm{Zn}^{2+}\right)$ enter normally empty interstitial holes in the open silicate framework. This high-temperature form is stabilized over the low-temperature $\alpha$-quartz due to the presence of $\mathrm{Al}^{3+}$ and $\mathrm{Zn}^{2+}$ cations. The structure of $\mathrm{Zn}_{\mathrm{x} / 2} \mathrm{Al}_{\mathrm{x}} \mathrm{Si}_{3-\mathrm{x}} \mathrm{O}_{6}$ has been studied recently based on the lithium stuffed derivative of $\beta$-quartz $\left(\mathrm{LiAlSi}_{2} \mathrm{O}_{6}\right)$ [45]. It was found that $\mathrm{Zn}^{2+}$ is located in tetrahedral (3a) positions.

ZAS s.s. transforms rapidly to $\beta$-quartz s.s. and willemite for the samples with low $\mathrm{Al}_{2} \mathrm{O}_{3}$ content. The $\beta$-quartz s.s. can correspond to the broad peak observed for ZAS75.12 at $950^{\circ} \mathrm{C}$ in Figure 3. The crystallization temperature is gradually shifted to lower temperatures for other samples due to the incorporation of $\mathrm{Al}$ and $\mathrm{Zn}$ in the $\beta$-quartz structure.

\section{Table 3}

Main crystalline phases determined by XRD at 850,950 and $1050^{\circ} \mathrm{C}$ (phases in brackets indicate small Bragg peak intensities and thus small amounts, as opposed to the other phases that are dominant).

\begin{tabular}{|c|c|c|c|}
\hline Sample & $850^{\circ} \mathrm{C}$ & $950^{\circ} \mathrm{C}$ & $1050^{\circ} \mathrm{C}$ \\
\hline ZAS75.12 & B-quartz s.s. & B-quartz s.s. & B-quartz s.s. \\
\hline ZAS60.10 & $\begin{array}{l}\text { ß-quartz s.s. } \\
\text { (cristobalite) }\end{array}$ & $\begin{array}{c}\text { B-quartz s.s. } / \alpha-\mathrm{Zn}_{2} \mathrm{SiO}_{4} / \\
\text { cristobalite }\end{array}$ & $\begin{array}{l}\alpha-\mathrm{Zn}_{2} \mathrm{SiO}_{4} / \text { gahnite / } \\
\text { cristobalite }\end{array}$ \\
\hline ZAS60.20 & ZAS s.s. & B-quartz s.s. / gahnite & $\begin{array}{l}\text { B-quartz s.s. / gahnite / } \\
\text { cristobalite }\end{array}$ \\
\hline ZAS50.10 & $\begin{array}{l}\text { ZAS s.s. / } \mathrm{B}^{-} \mathrm{Zn}_{2} \mathrm{SiO}_{4} \\
\text { / (mullite) }\end{array}$ & ZAS s.s. $/ \alpha-\mathrm{Zn}_{2} \mathrm{SiO}_{4}$ & $\alpha-\mathrm{Zn}_{2} \mathrm{SiO}_{4} /$ gahnite \\
\hline ZAS50.20 & ZAS s.s. / mullite & gahnite $/ \alpha-\mathrm{Zn}_{2} \mathrm{SiO}_{4}$ & gahnite $/ \alpha-\mathrm{Zn}_{2} \mathrm{SiO}_{4}$ \\
\hline ZAS50.25 & ZAS s.s. & ZAS s.s. / gahnite & gahnite \\
\hline ZAS40.15 & $\begin{array}{l}\text { ZAS s.s. / } \mathrm{B}-\mathrm{Zn}_{2} \mathrm{SiO}_{4} \\
\text { - } \mathrm{ZnO} / \text { mullite }\end{array}$ & $\begin{array}{c}\alpha-\mathrm{Zn}_{2} \mathrm{SiO}_{4}\left(\left(\mathrm{~B}-\mathrm{Zn}_{2} \mathrm{SiO}_{4}\right) /\right. \\
\text { gahnite }\end{array}$ & $\alpha-\mathrm{Zn}_{2} \mathrm{SiO}_{4} /$ gahnite \\
\hline ZAS40.10 & $\begin{array}{l}\text { ZAS s.s. / } \beta-\mathrm{Zn}_{2} \mathrm{SiO}_{4} \\
\text { - } \mathrm{ZnO} / \text { (mullite) }\end{array}$ & $\begin{array}{c}\alpha-\mathrm{Zn}_{2} \mathrm{SiO}_{4}\left(\mathrm{~B}_{-}-\mathrm{Zn}_{2} \mathrm{SiO}_{4}\right) / \\
\mathrm{ZAS} \text { s.s. }\end{array}$ & $\alpha-\mathrm{Zn}_{2} \mathrm{SiO}_{4} /$ gahnite \\
\hline ZAS35.10 & $\begin{array}{l}\mathrm{B}_{-} \mathrm{Zn}_{2} \mathrm{SiO}_{4} / \alpha- \\
\mathrm{Zn}_{2} \mathrm{SiO}_{4}(\mathrm{ZnO})\end{array}$ & $\begin{array}{c}\alpha-\mathrm{Zn}_{2} \mathrm{SiO}_{4}\left(\mathrm{~B}-\mathrm{Zn}_{2} \mathrm{SiO}_{4}\right) / \\
\text { (gahnite) }\end{array}$ & $\begin{array}{c}\alpha-\mathrm{Zn}_{2} \mathrm{SiO}_{4}\left(\mathrm{~B}_{-} \mathrm{Zn}_{2} \mathrm{SiO}_{4}\right) / \\
\text { gahnite }\end{array}$ \\
\hline
\end{tabular}

At $950^{\circ} \mathrm{C}$, gahnite can be detected for compositions near the center of the ternary (ZAS60.20, ZAS50.25, ZAS50.20 and ZAS40.15) and, at $1050^{\circ} \mathrm{C}$, gahnite is observed in compositions of 
low $\mathrm{Al}_{2} \mathrm{O}_{3}$ content (ZAS60.10, ZAS50.10, ZAS40.10 and ZAS35.10). This phase is the only one present in ZAS50.25 at $1050^{\circ} \mathrm{C}$. Willemite appears for glass composition near the binary $\mathrm{ZnO}-\mathrm{SiO}_{2}$, with $\mathrm{B}-\mathrm{Zn}_{2} \mathrm{SiO}_{4}$ crystallizing first, before its transformation in $\alpha-\mathrm{Zn}_{2} \mathrm{SiO}_{4}$ as temperature increases. 

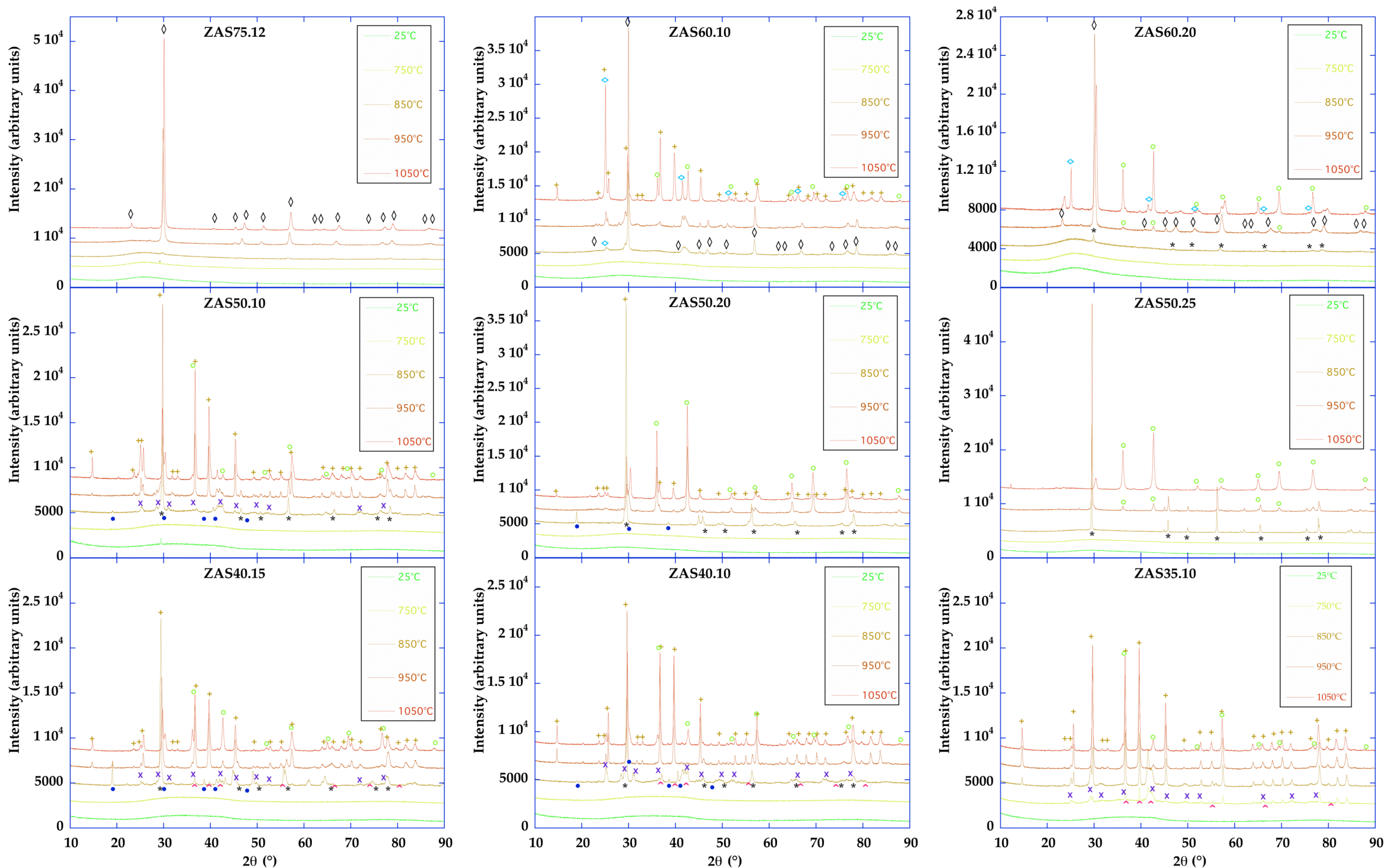
Fig. 4. XRD patterns representative glasses heat treated at various temperatures $\left(25^{\circ} \mathrm{C}, 750{ }^{\circ} \mathrm{C}\right.$, $\left.850{ }^{\circ} \mathrm{C}, 950{ }^{\circ} \mathrm{C}, 1050{ }^{\circ} \mathrm{C}, 1150^{\circ} \mathrm{C}\right)$. Crystalline phases are identified with the following symbols: $*=$ ZAS-s.s. (ICDD card $\left.\mathrm{N}^{\circ} 00-032-1455\right) ; \diamond=ß$-quartz s.s. (ICDD card $\mathrm{N}^{\circ} 01-075-$ $1555){ }^{\circ}=$ gahnite $\left(\right.$ ICDD card $\left.\mathrm{N}^{\circ} 01-074-1138\right) ; \diamond=$ cristobalite ((ICDD card $\mathrm{N}^{\circ} 01-077-$ $8675) ;+=\alpha-\mathrm{Zn}_{2} \mathrm{SiO}_{4}\left(\mathrm{ICDD}\right.$ card $\left.\mathrm{N}^{\circ} 00-008-0492\right) ; \mathbf{x}=\beta-\mathrm{Zn}_{2} \mathrm{SiO}_{4}(\mathrm{ICDD}$ card No 00-0140653); $\bullet=$ mullite $\left(\right.$ ICDD $\left.\operatorname{card~} \mathrm{N}^{\circ} 01-089-2814\right) ; \stackrel{\wedge}{=} \mathrm{ZnO}\left(\mathrm{ICDD}\right.$ card $\mathrm{N}^{\circ}$ 01-071-3830).

\subsection{Aluminum speciation}

${ }^{27} \mathrm{Al}$ NMR spectra are shown in Fig 5. The signal exhibits a broad asymmetric lineshape with two shoulders and span the range of ${ }^{[4]} \mathrm{Al},{ }^{[5]} \mathrm{Al}$ and ${ }^{[6]} \mathrm{Al}$. The lineshape is due to distribution of both quadrupolar interactions and chemical shift, regularly observed in disordered materials like glasses. ${ }^{27} \mathrm{Al} \mathrm{MQ}-\mathrm{MAS}$ spectra have been systematically acquired for all samples. Figure 6 shows the example of ${ }^{27} \mathrm{Al}$ MAS and MQ-MAS spectra for ZAS75.12 glass. The $2 \mathrm{D}$ spectrum indicates clearly that the signal is composed of at least two contributions attributed to ${ }^{[4]} \mathrm{Al}$ and ${ }^{[5]} \mathrm{Al}$. As previously done [1][4], the quantitative MAS spectra are simulated using the NMR parameters extracted from more resolved MQ-MAS spectra. Table 4 groups the isotropic chemical shift $\left(\delta_{\text {iso }}\right)$ and proportions of each aluminum species. In all cases, ${ }^{[4]} \mathrm{Al}$ is the main component, but higher coordinated species are also detected as previously observed in MAS and CAS glasses [46][3][47][4] or in sodium aluminosilicate glasses containing $\mathrm{ZnO}$ [48]. The chemical shift for ${ }^{[4]} \mathrm{Al}$ varies by about $6 \mathrm{ppm}$ between ZAS75.12 and ZAS40.15 samples. The variation depends upon both the $\mathrm{Si} / \mathrm{Al}$ connectivity and the $\mathrm{ZnO}$ content then a correlation between the chemical shift and composition will require a systematic investigation over a large range of sample composition. A recent study on $\mathrm{Ca}-\mathrm{Mg}$ aluminosilicate glasses suggest that the content in $\mathrm{M}^{2+}$ ions is more important than the $\mathrm{Si} / \mathrm{Al}$ ratio [49]. 

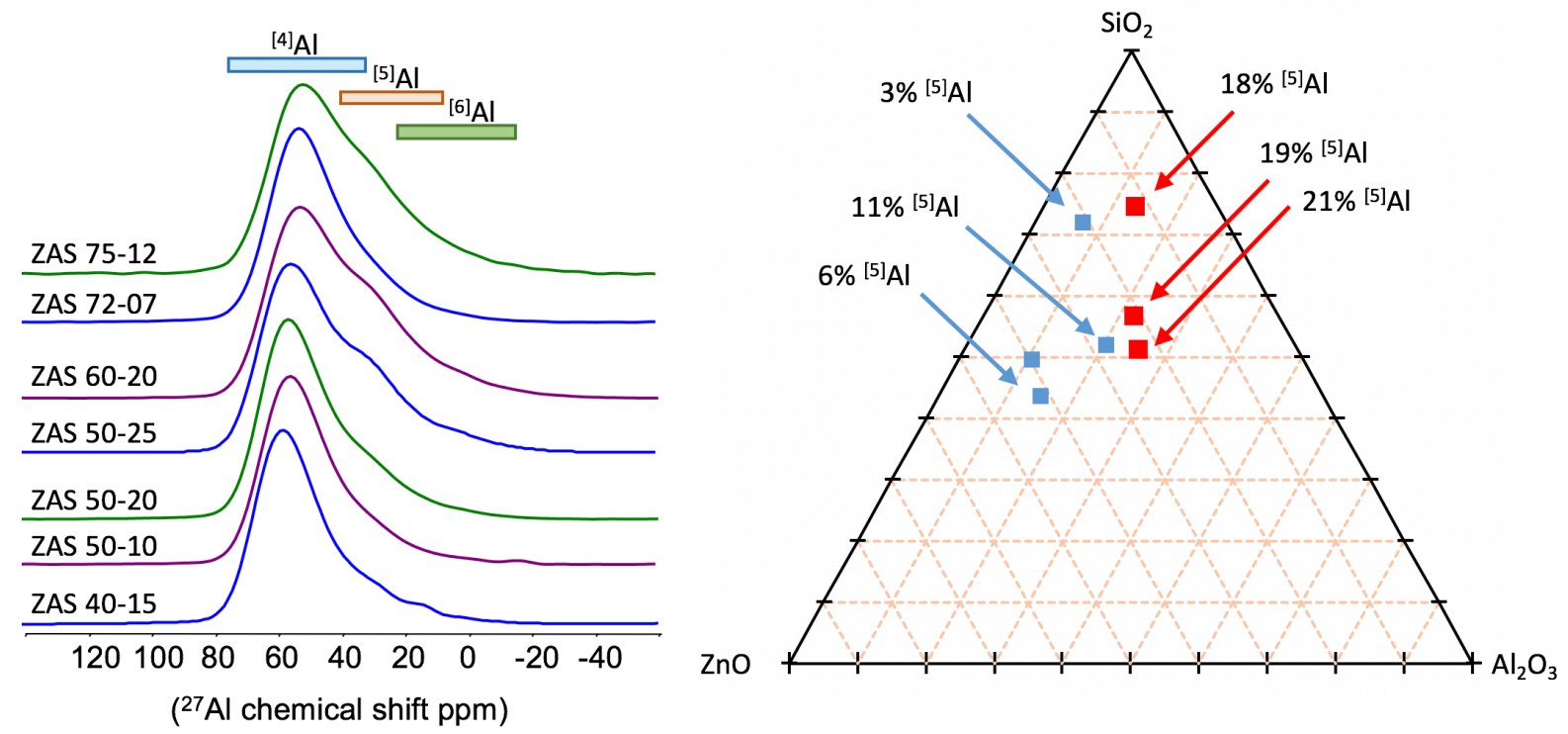

Fig. 5. (Left) ${ }^{27} \mathrm{Al} 1 \mathrm{D}$ NMR spectra for the ZAS glasses. (Right) Proportion of ${ }^{[5]} \mathrm{Al}$ in the ternary ZAS system.
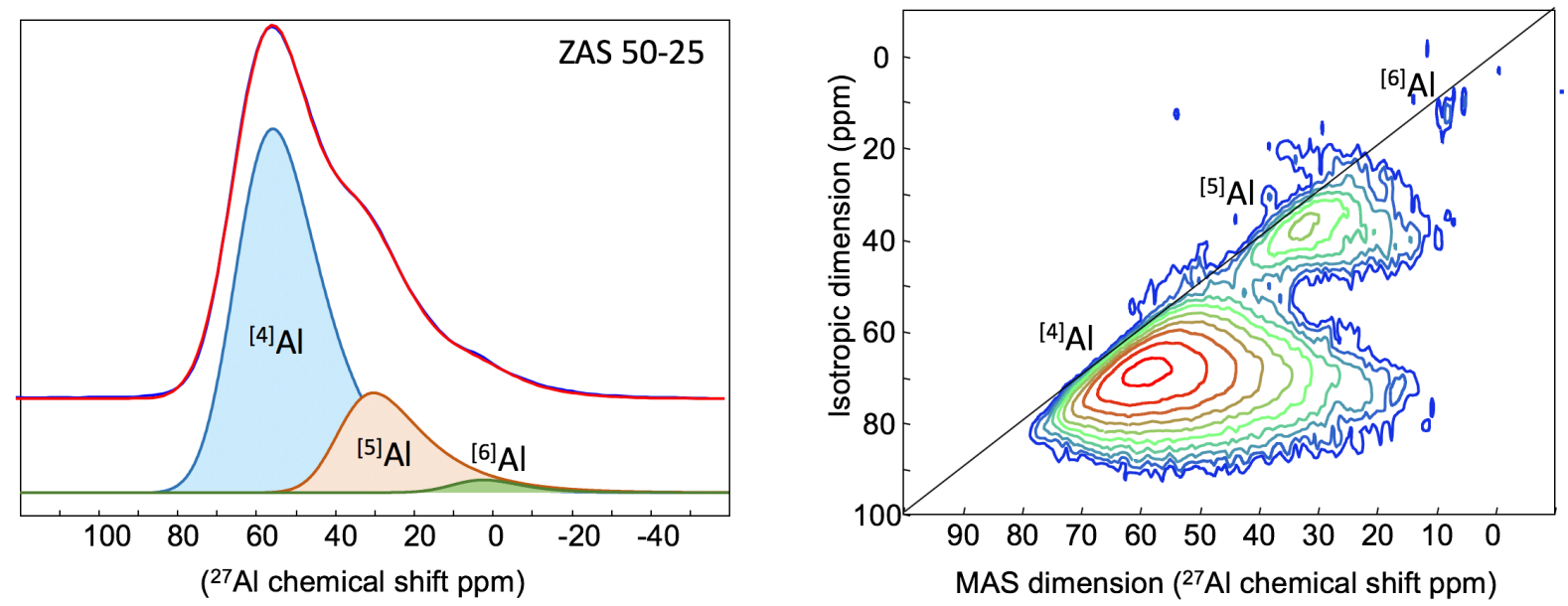

Fig. 6. (Left) Typical ${ }^{27} \mathrm{Al} 1 \mathrm{D}$ NMR spectrum (left) and (right) contour plot of the ${ }^{27} \mathrm{Al}$ MQ-MAS NMR spectrum for the ZAS50.25 glass. The bottom curves of the left panel are fitted peaks for the three different $\mathrm{Al}$ sites. 


\section{Table 4}

Isotropic chemical shift (ppm) and proportion of ${ }^{[n]} \mathrm{Al}$ species corresponding to the percentage of $\mathrm{Al}$ atoms coordinated by $n$ oxygen anions obtained from the ${ }^{27} \mathrm{Al}$ NMR analysis. The uncertainties are estimated to $\pm 0.5 \mathrm{ppm}$ and $\pm 1 \%$ for chemical shift and proportion respectively.

\begin{tabular}{|c|c|c|c|c|c|c|}
\hline Sample & \multicolumn{2}{|c|}{${ }^{[4]} \mathbf{A l}$} & \multicolumn{2}{c|}{${ }^{[5]} \mathbf{A l}$} & \multicolumn{2}{c|}{${ }^{[6]} \mathbf{A l}$} \\
\hline & $\delta_{\text {iso }}(\mathbf{p p m})$ & $\%$ & $\boldsymbol{\delta}_{\text {iso }}(\mathbf{p p m})$ & $\%$ & $\boldsymbol{\delta}_{\text {iso }}(\mathbf{p p m})$ & $\%$ \\
\hline ZAS75.12 & 61.9 & 80 & 38.0 & 18 & 15.4 & 2 \\
\hline ZAS72.07 & 62.1 & 97 & 32.2 & 3 & & - \\
\hline ZAS60.20 & 64.2 & 79 & 35.9 & 19 & 9.75 & 2 \\
\hline ZAS50.25 & 64.7 & 77 & 39.4 & 21 & 8.9 & 2 \\
\hline ZAS50.20 & 65.7 & 88 & 38.4 & 11 & 9.7 & 1 \\
\hline ZAS50.10 & 64.7 & 94 & 35.0 & 6 & - & - \\
\hline ZAS40.15 & 67.1 & 93 & 37.3 & 6 & 16.2 & 1 \\
\hline
\end{tabular}

\subsection{Neutron and X-ray diffraction and MD simulations}

Neutron and X-ray diffraction were acquired on the ZAS50.25 sample and compared with MD simulations. A quantitative fit of the diffraction data was not tempted due to the overlap of several pairs (Si-O, ${ }^{[4]} \mathrm{Al}-\mathrm{O},{ }^{[5]} \mathrm{Al}-\mathrm{O}$ and $\left.\mathrm{Zn}-\mathrm{O}\right)$. The ZAS50.25 model obtained by MD is qualitatively close to experimental diffraction data, since the main features of the structure factors and PDF functions are reproduced (Fig. 7). However, this model bears significant differences in intensities at low-Q values indicating that the medium range order is not perfectly reproduced by the MD simulations.

The Al-O Partial PDF (PPDF) shows a first peak at $1.8 \AA$, followed by a minimum at $2.35 \AA$ (Fig. 8a), which was used for the cut-off distance to calculate coordination numbers. ${ }^{[4]} \mathrm{Al},{ }^{[5]} \mathrm{Al}$ and ${ }^{[6]} \mathrm{Al}$ are found in proportion $58 \%, 35 \%$ and $7 \%$ (Fig. $8 \mathrm{~b}$ ). These values are higher than those determined by NMR $(77 \%, 21 \%$ and $2 \%)$ but are qualitatively consistent with a high proportion of high coordinated species. The large values can result from the fast quenching rate that is intrinsically a limit of the MD method.

Similarly, the Zn-O PPDF has a first peak centered at $2.0 \AA$, followed by a minimum at $2.5 \AA$ (Fig. 8c). The site distribution shows different sites with 4-, 5- and 6-fold coordination (Fig. 8d). Using a cut-off at $2.5 \AA$, a majority of 4 -fold (43\%) and 5-fold (48\%) sites are determined. 
Again, overestimation of high coordinated sites might be induced by the MD quenching rate but the results indicate that high-coordinated $\mathrm{Zn}$ sites are present in ZAS glasses.
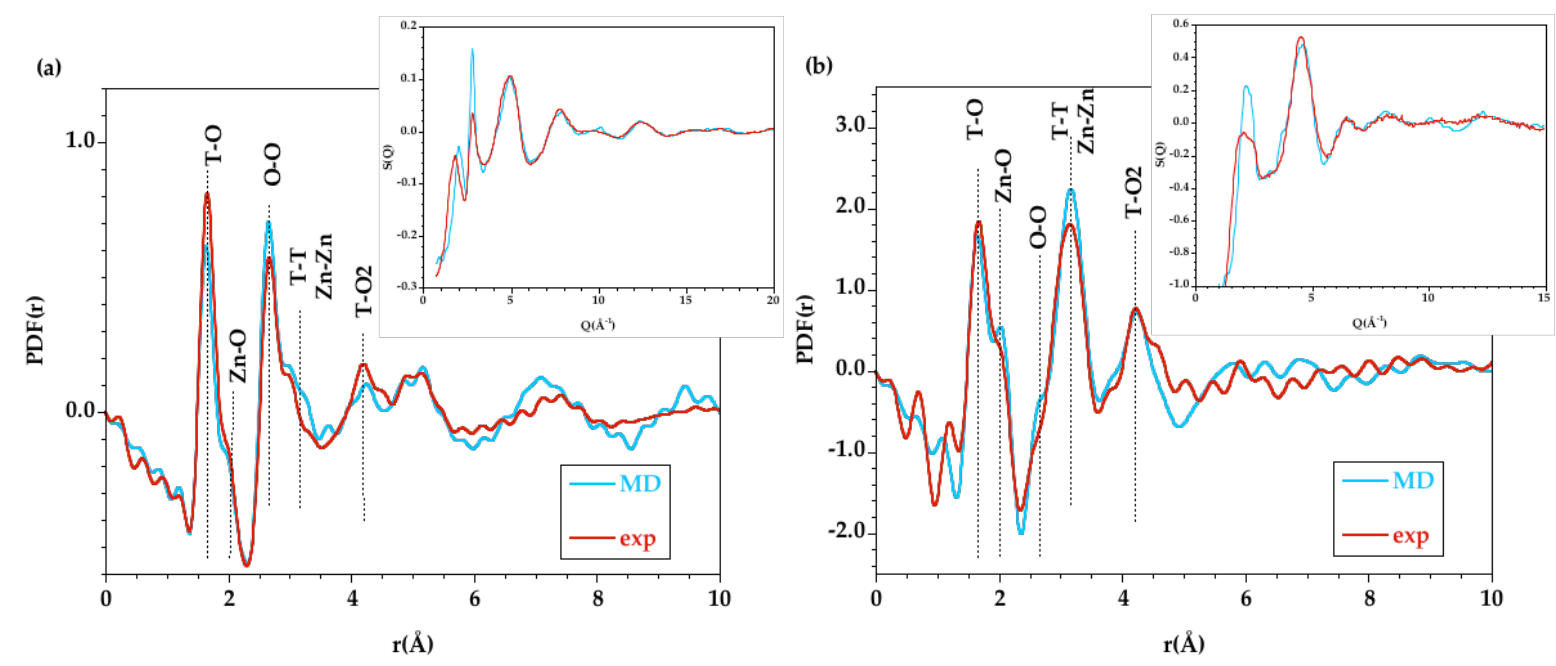

Fig. 7. Comparison of the PDF functions for ZAS50.25 between the MD model and the experimental one for (a) neutron diffraction and (b) X-ray diffraction data. The inserts compare the MD and experimental structure factors.
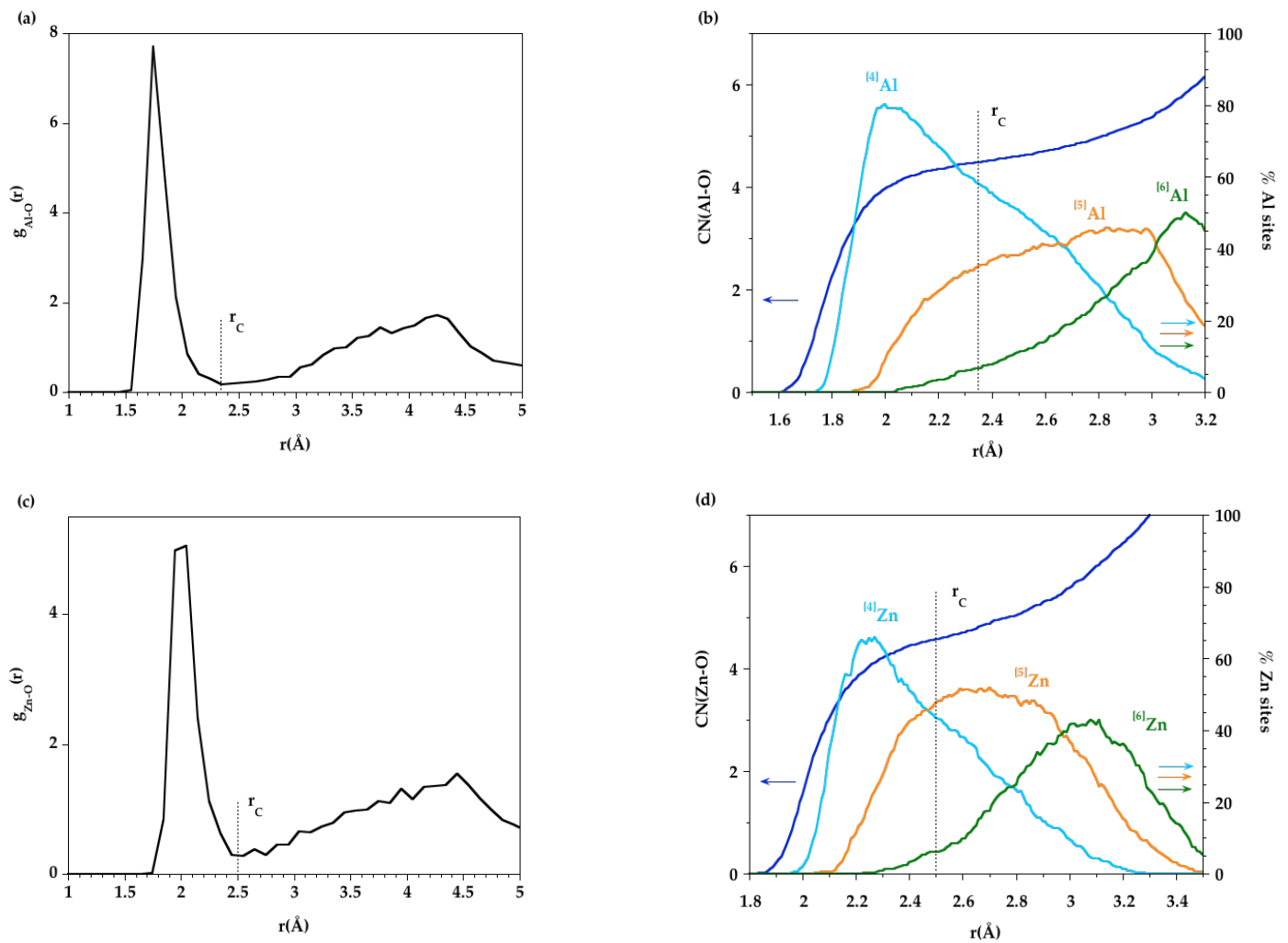

Fig. 8. (a) Al-O PPDF extracted from MD model of a ZAS50.25 glass, showing the cut-off distance $\mathrm{r}_{\mathrm{C}}$ used to calculated the average coordination number. (b) Evolution with the cutoff 
distance of the Al-O average coordination number (right axis) and of the cation site distribution (left axis) for $\mathrm{Al}$ in a MD model of a ZAS50.25 glass. (c) Zn-O PPDF extracted from MD model of a ZAS50.25 glass, showing the cut-off distance $\mathrm{r}_{\mathrm{C}}$ used to calculated the average coordination number. (d) Evolution with the cutoff distance of the $\mathrm{Zn}-\mathrm{O}$ average coordination number (right axis) and of the cation site distribution (left axis) for $\mathrm{Zn}$ in a MD model of a ZAS50.25 glass.

\section{Discussion}

\subsection{Glass forming ability}

The glass forming ability (GFA) in the ZAS ternary has received little attention. GFA measures the ease for producing a glass upon cooling above liquidus temperature, which is related to the critical cooling rate needed to avoid crystallization. The GFA can be assessed by the resistance of a glass against crystallization upon reheating, which is defined as the glass stability (GS) [50].

The GFA for ZAS can be compared with other divalent cations $\left(\mathrm{Mg}^{2+}, \mathrm{Ca}^{2+}, \mathrm{Sr}^{2+}\right)$ $[51][46][4][52]$. While the vitrification ability at high concentrations of $\mathrm{Al}_{2} \mathrm{O}_{3}$ is limited in aluminosilicate systems containing monovalent or divalent cations, the CAS and SAS (SrO$\mathrm{Al}_{2} \mathrm{O}_{3}-\mathrm{SiO}_{2}$ ) ternaries are atypical since glasses can be formed with very low $\mathrm{SiO}_{2}$ amount and up to the $\mathrm{CaO}-\mathrm{Al}_{2} \mathrm{O}_{3}$ binary for the CAS system. Opposite to these systems, the ZAS and MAS systems show very similar glass forming domains except that $\mathrm{MgO}-\mathrm{SiO}_{2}$ glasses can be obtained in a narrow compositional range from 50 to $33 \mathrm{~mol} \% \mathrm{SiO}_{2}$ [53][54]. Since no binary $\mathrm{ZnO}-\mathrm{SiO}_{2}$ glasses can be formed, $\mathrm{Zn}^{2+}$ ions have a lesser GFA compared to $\mathrm{Mg}^{2+}$. However, the lower $\mathrm{SiO}_{2}$ content of MAS glasses is $42 \mathrm{~mol} \%$ (MAS42.14) while $\mathrm{SiO}_{2}$ content of $30 \mathrm{~mol} \%$ can be reached for ZnO-rich glasses (ZAS35.10). In spite of these differences, the overall similarity between ZAS and MAS glass forming domains suggests a similar structural role for $\mathrm{Zn}^{2+}$ and $\mathrm{Mg}^{2+}$ cations. 


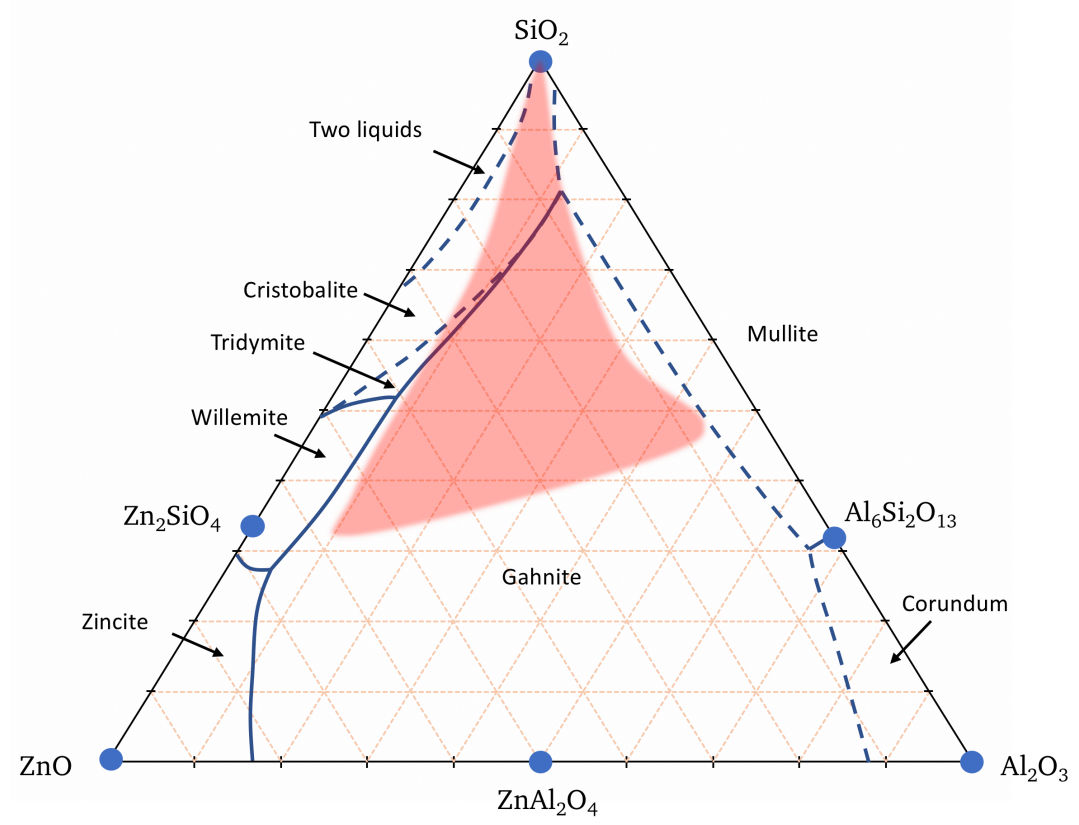

Fig. 9. The $\mathrm{ZnO}-\mathrm{Al}_{2} \mathrm{O}_{3}-\mathrm{SiO}_{2}$ ternary phase diagram (data from [31]) showing the crystalline phases and the glass forming region in red.

From the phase diagram [31], it can be observed an increase in the melting temperature for high amount of $\mathrm{Al}_{2} \mathrm{O}_{3}$ or $\mathrm{ZnO}$, which is related to a decrease in the GFA, explaining the difficulties to obtain glasses in the lower part of the ternary (Fig. 9). During our synthesis experiments, significant volatilization can occur for these compositions. The ZAS phase diagram is characterized by few binary crystals (gahnite $\mathrm{ZnAl}_{2} \mathrm{O}_{4}$, willemite $\mathrm{Zn}_{2} \mathrm{SiO}_{4}$, mullite $\mathrm{Al}_{6} \mathrm{Si}_{2} \mathrm{O}_{13}$ ) and no ternary compounds (Fig. 9). A wide range of compositions, covering the glass forming domain, is dominated by the stability region of gahnite.

The crystalline phases appearing in the course of controlled thermal treatment were determined by DTA and HT-XRD analysis. The same average heating ramp was applied in both measurements but HT-XRD patterns were recorded over a plateau of $45 \mathrm{~min}$. Diffraction wit lower acquisition time could be obtained on synchrotron and will allow to have similar heating treatment than DTA allowing a better interpretation of the thermodynamics events and allowing the potential observation of metastable phases. The first phase appearing is a metastable zinc aluminosilicate solid solution (ZAS s.s.), corresponding to the first exothermic peak on DTA scans $\left(850-950^{\circ} \mathrm{C}\right)$. It was shown that crystallization of ZAS s.s. occurs mostly on the surface [45]. With increasing temperature $\left(950-1050^{\circ} \mathrm{C}\right)$, this phase decomposes into binary phases and gahnite. Simultaneously to the formation of the binary phases, the exsolution of $\mathrm{Zn}$ and $\mathrm{Al}$ from the ZAS s.s. results into the formation of $\beta$-quartz s.s. (high-temperature 
quartz). This is in agreement with a previous study showing the initial crystallization of $\beta$-quartz s.s. or $\beta$-willemite s.s. between $820-900^{\circ} \mathrm{C}$ [39]. When the $\mathrm{SiO}_{2}$ content is less than $50 \mathrm{~mol} \%$ (ZAS40.15), ZAS s.s. formation does not occur and $\mathrm{B}-\mathrm{Zn}_{2} \mathrm{SiO}_{4}$ phase is detected first at $750{ }^{\circ} \mathrm{C}$ then this phase transforms at higher temperature to $\alpha-\mathrm{Zn}_{2} \mathrm{SiO}_{4}$.

We were particularly interested in the influence of glass composition on crystallization path of gahnite. This latter phase does not crystallize during the first exothermic peak, but it is associated with the second or third exothermic event. With higher amount of $\mathrm{ZnO}$ and $\mathrm{Al}_{2} \mathrm{O}_{3}$, gahnite crystallizes in the third stage after the formation of willemite and B-quartz s.s., though these glass compositions are still in the stability field of gahnite. Willemite and gahnite appear after exsolution of $\mathrm{Al}^{3+}$ and $\mathrm{Zn}^{2+}$ from the ZAS s.s.. Willemite is favored near the $\mathrm{ZnO}-\mathrm{SiO}_{2}$ join according to the phase diagram, while gahnite is the dominant phase near the $\mathrm{ZnAl}_{2} \mathrm{O}_{4}$ $\mathrm{SiO}_{2}$ tectosilicate join. Gahnite formation is important around the ZAS50.25 glass composition in which gahnite can even be the only phase present at $1050^{\circ} \mathrm{C}$. In the DTA curve, this phase corresponds to the pronounced crystallization peak near $1000^{\circ} \mathrm{C}$.

\subsection{Influence of Al speciation on GS}

Aluminum usually improves glass formation for systems containing divalent cations. Indeed the glass forming range in $\mathrm{M}^{2+}-\mathrm{O}-\mathrm{SiO}_{2}$ binary is limited, for instance around enstatite $\left(\mathrm{MgSiO}_{3}\right)$ or wollastonite $\left(\mathrm{CaSiO}_{3}\right)$ compositions, and an important liquid-liquid immiscibility is well known at high $\mathrm{SiO}_{2}$ content [51][46][4][52]. Addition of $\mathrm{Al}_{2} \mathrm{O}_{3}$ increases the network connectivity resulting in higher viscosity and lower crystallization kinetics. The tectosilicate compositions are particularly prone to vitrification and can allow very low $\mathrm{SiO}_{2}$ content, as for $\mathrm{CaO}$ and $\mathrm{SrO}$ aluminosilicate glasses.

As observed in previous studies of aluminosilicate glasses containing divalent cations $[46][3][47][4][52],{ }^{27} \mathrm{Al}$ NMR spectra reveal that aluminum is in majority four-fold coordinated but there is a large concentration of ${ }^{[5]} \mathrm{Al}$ and, to a lesser extent, of ${ }^{[6]} \mathrm{Al}$ for all glass compositions investigated. The behavior is different in alkali aluminosilicate glasses in which almost only ${ }^{[4]} \mathrm{Al}$ species is evidenced [55][56]. Comparison with other systems containing divalent cations (Fig. 10) shows that ZAS glasses have the highest proportion of ${ }^{[5]} \mathrm{Al}$ species for glasses along the tectosilicate join. Formation of ${ }^{[5]} \mathrm{Al}$ is favored in the order $\mathrm{Zn}^{2+}>\mathrm{Mg}^{2+}>$ $\mathrm{Ca}^{2+}>\mathrm{Sr}^{2+}, \mathrm{Ba}^{2+}>$ alkalis [48][52][46][4]. This behavior is in agreement with the assumption that cation field strength (CFS), defined by the ratio $\mathrm{z} / \mathrm{r}^{2}$ with $\mathrm{z}$ and $\mathrm{r}$ denoting the charge and 
cation-oxygen bond length (Table 5), controls the formation of five-fold coordinated aluminum; the higher the CFS the higher the proportion of ${ }^{[5]} \mathrm{Al}[57][58][48]$.

\section{Table 5}

Valence, cation-oxygen distance and cation field strength.

\begin{tabular}{|l|l|l|l|}
\hline Cation & valence & $\begin{array}{l}\text { cation-oxygen bond } \\
\text { length }\end{array}$ & $\begin{array}{l}\text { Cation } \\
\text { strength }\end{array}$ \\
\hline $\mathrm{Al}^{3+}$ & 3 & $1.77[59]$ & 0.96 \\
\hline $\mathrm{Zn}^{2+}$ & 2 & $1.96[60]$ & 0.52 \\
\hline $\mathrm{Mg}^{2+}$ & 2 & $2.00[61]$ & 0.50 \\
\hline $\mathrm{Ca}^{2+}$ & 2 & $2.35[60]$ & 0.36 \\
\hline $\mathrm{Sr}^{2+}$ & 2 & $2.62[60]$ & 0.29 \\
\hline
\end{tabular}

The proportion of ${ }^{[5]} \mathrm{Al}$ does not increase continuously with $\mathrm{Al}_{2} \mathrm{O}_{3}$ addition. The ${ }^{[5]} \mathrm{Al}$ content increases from the $\mathrm{M}^{2+} \mathrm{O}-\mathrm{SiO}_{2}$ join towards the tectosilicate join. A maximum in the proportion of ${ }^{[5]} \mathrm{Al}$ is observed in aluminosilicate systems close to the center of the tectosilicate compositions at $40-50 \mathrm{~mol}^{\circ} \mathrm{SiO}_{2}$. For low-silica CAS and SAS glasses [1][52], the ${ }^{[5]} \mathrm{Al}$ content decreases markedly near the aluminate compositions. No such maxima can be observed in the ZAS system which is limited to glasses with $\mathrm{SiO}_{2}$ content higher than $50 \mathrm{~mol} \%$.

High-coordinated Al species are not energetically stable and they should have significant influence for many properties, especially those related to transport mechanisms. The loss of GS when going to the peraluminous region was proposed to be related to the formation of ${ }^{[5]} \mathrm{Al}$ [62]. The presence of ${ }^{[5]} \mathrm{Al}$ can directly (as nucleation site for the crystal formation) or indirectly (due to fluctuations in structural organization to compensate this site) impact the crystallization behavior. For instance, gahnite formation seems favored in the composition domain containing a high ${ }^{[5]} \mathrm{Al}$ proportion. The high-coordinated species also modify the local viscosity. As proposed in previous investigations on CAS glasses $[1][46],{ }^{[5]} \mathrm{Al}$ can be a transition state similar to ${ }^{[5]} \mathrm{Si}$ species determined in alkali silicate melts and both species can play an important role in the mechanisms of viscous flow [63]. 

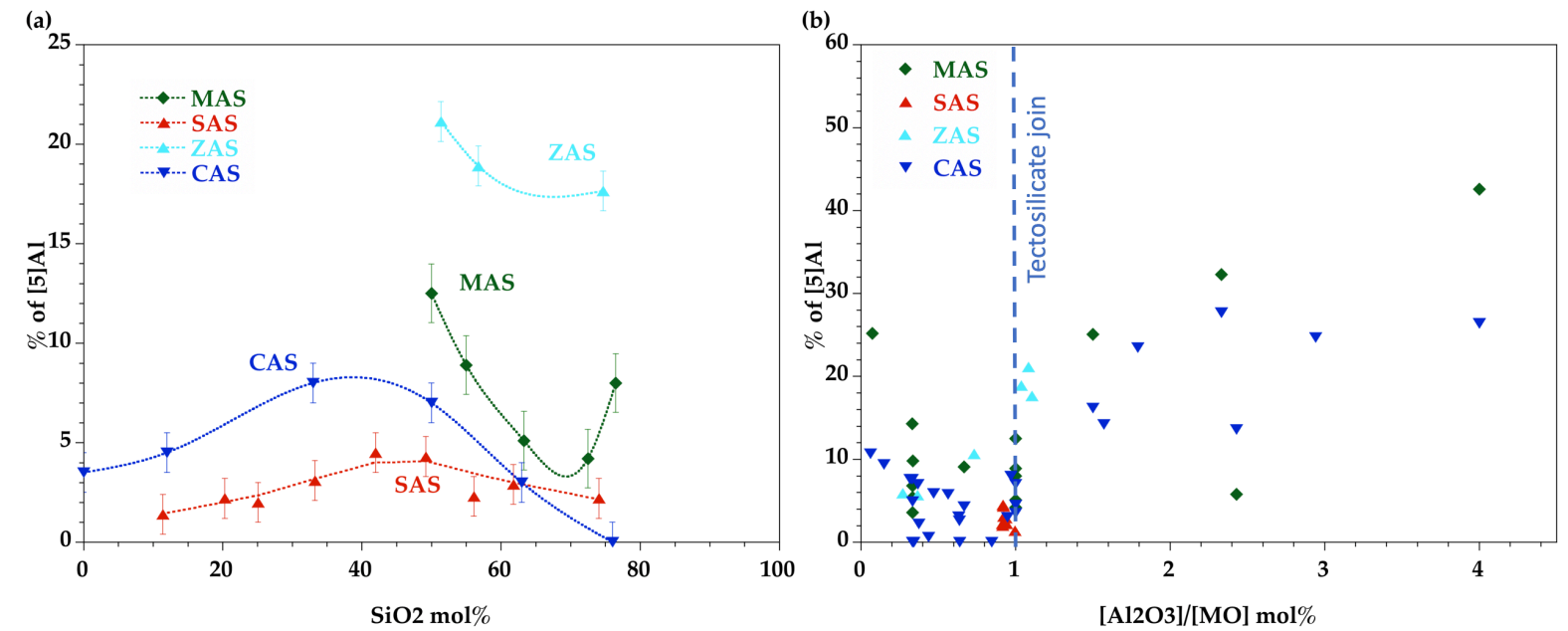

Fig. 10. Comparison of the proportion of ${ }^{[5]} \mathrm{Al}$ in aluminosilicate glasses containing divalent cations $\left(\mathrm{Mg}^{2+}:\right.$ MAS; $\left.\mathrm{Ca}^{2+}: \mathrm{CAS} ; \mathrm{Sr}^{2+}: \mathrm{SAS} ; \mathrm{Zn}^{2+}: \mathrm{ZAS}\right)$ (a) as a function of the $\mathrm{SiO}_{2}$ content for a constant ratio $\mathrm{M}^{2+} \mathrm{O} / \mathrm{Al}_{2} \mathrm{O}_{3}=1$ (curves are guides for the eye) and (b) as a function of the ratio $\mathrm{Al}_{2} \mathrm{O}_{3} / \mathrm{M}^{2+} \mathrm{O}$.

\subsection{Role of zinc}

In crystalline structures, $\mathrm{Zn}^{2+}$ is mostly tetrahedrally coordinated $\left(\alpha-\mathrm{Zn}_{2} \mathrm{SiO}_{4}\right.$ [64], $\left.\mathrm{ZnO}\right)$ with $\mathrm{Zn}-\mathrm{O}$ distances in the range 1.85-2.04 $\AA$ and, rarely, octahedrally coordinated with longer $\mathrm{Zn}$-O distances 1.98-2.26 $\AA$. This latter is not favored due to its $3 \mathrm{~d}^{10}$ electronic configuration and a high polarizability of $\mathrm{Zn}^{2+}$ ion.

However, in oxide glasses, 5-fold coordinated $\mathrm{Zn}$ is also suggested. In alkali silicate glasses, $\mathrm{Zn}$ is mainly tetrahedrally coordinated at high $\mathrm{SiO}_{2}$ content, and octahedral sites appear when $\mathrm{SiO}_{2}<50 \mathrm{~mol} \%$ as suggested by X-ray diffraction [21]. However, authors concluded that "the coordination is close to, but significantly greater than, 4". Similarly MD simulations of $\mathrm{Na}_{2} \mathrm{O}-$ $\mathrm{ZnO}-\mathrm{SiO}_{2}$ glasses indicate that 5-fold coordinated $\mathrm{Zn}$ species increase with increasing $\mathrm{ZnO}$ content and this coordination can become majority at high $\mathrm{ZnO}$ content ( $>40 \mathrm{~mol} \%$ ) [65]. In Mg aluminosilicate glasses [19], EXAFS suggest a tetrahedral environment but the authors have underlined that irregular $\mathrm{Zn}$ configuration should be present. In the present study, the MD simulation of ZAS50.25 glass confirm that $\mathrm{Zn}$ is almost equally distributed on 4-fold and 5fold sites (Fig. 8).

Pentacoordination is not uncommon in glasses and can be observed for $\mathrm{Mg}$ or transition elements (Ti, $\mathrm{Ni}, \mathrm{Fe})$ [61][66][60]. It is particularly interesting that $\mathrm{Zn}^{2+}$ and $\mathrm{Mg}^{2+}$ adopt similar site speciation with relatively lower coordination compared to $\mathrm{Ca}^{2+}, \mathrm{Sr}^{2+}$ or $\mathrm{Ba}^{2+}$. 
High field strength cations tend to bond relatively strongly to oxygens and to be able to dictate their own local environment. They can be considered to play an intermediate role between network formers and network modifiers in glass structure. Increasing CFS enhanced the network disorder [67][68] and favor high coordinated Al species. Indeed, the low ${ }^{[4]} \mathrm{Zn}$ coordination sites suggest that $\mathrm{Zn}$ can compete with aluminum in network forming positions. A significant proportion of $\mathrm{Zn}$ is thus not available for charge compensation of $\left(\mathrm{AlO}_{4}\right)^{-}$ tetrahedra. Furthermore ${ }^{[4]} \mathrm{Zn}$ can be located in interstitial position in the aluminosilicate network and distort the structure, which could also favor the formation of ${ }^{[5]} \mathrm{Al}$. This behavior is more associated with a modifying role though $\mathrm{Zn}$ has a low coordination number.

\section{Conclusions}

The $\mathrm{ZnO}-\mathrm{Al}_{2} \mathrm{O}_{3}-\mathrm{SiO}_{2}$ (ZAS) ternary system has been investigated to determine the glass forming region and the crystallization behavior. The range of vitrification for ZAS is similar to $\mathrm{MgO}-\mathrm{Al}_{2} \mathrm{O}_{3}-\mathrm{SiO}_{2}$ system with no glass formation possible along the $\mathrm{ZnO}-\mathrm{SiO}_{2}$ binary and the ability to elaborate glasses for high $\mathrm{ZnO}$ - poor $\mathrm{Al}_{2} \mathrm{O}_{3}$ compositions. The first crystalline phases to appear are willemite near the $\mathrm{ZnO}-\mathrm{SiO}_{2}$ binary and a metastable zinc aluminosilicate solid solution for other compositions. With further heat treatments, this latter phase gives binary phases and gahnite. Near the $\mathrm{ZnAl}_{2} \mathrm{O}_{4}-\mathrm{SiO}_{2}$ join, gahnite is mostly favored and becomes the main phase for ZAS50.25 glass composition. The structure was investigated using ${ }^{27} \mathrm{Al}$ NMR, neuron and X-ray diffraction coupled with Molecular Dynamics. As for other aluminosilicate systems, ${ }^{[4]} \mathrm{Al}$ is the dominant species but a large fraction of ${ }^{[5]} \mathrm{Al}$ is present especially close to the tectosilicate join. $\mathrm{Zn}$ is also distributed between four-fold and five-fold coordinated sites, which could imply a dual structural role.

\section{Declaration of competing interest}

The authors declare that they have no known competing interests or personal relationships that could have appeared to influence the work reported in this paper.

\section{Credit authorship contribution statement}

Laurent Cormier: conceptualization, methodology, formal analysis writing - original draft, supervision. Ludovic Delbes: investigation, writing - review \& editing. Benoit Baptiste : investigation, writing - review \& editing. Valérie Montouillout: methodology, investigation, formal analysis, writing - review \& editing. 


\section{Acknowledgment}

We gratefully thank Joan Brahamcha-Marin for his help in glass synthesis and DTA measurements and Brigitte Beuneu and Jacques Darpentigny for appreciable supports in neutron data acquisition. Financial support from the IR-RMH-THC FR3050 CNRS for conducting the research is gratefully acknowledged.

\section{References}

[1] D.R. Neuville, L. Cormier, D. Massiot, Al coordination and speciation in calcium aluminosilicate glasses: effects of composition determined by 27Al MQ-MAS NMR and Raman spectroscopy, Chem Geol. 229 (2006) 173-185.

[2]D.R. Neuville, L. Cormier, D. Massiot, Al environment in tectosilicate and peraluminous glasses: a 27Al MQ-MAS NMR, Raman, and EXAFS investigation, Geochim Cosmochim Acta. 68 (2004) 5071-5079.

[3]M. Guignard, L. Cormier, Environments of $\mathrm{Mg}$ and $\mathrm{Al}$ in $\mathrm{MgO}-\mathrm{Al} 2 \mathrm{O} 3-\mathrm{SiO} 2$ glasses: A study coupling neutron and X-ray diffraction and Reverse Monte Carlo modeling, Chem. Geol. 256 (2008) 111-118.

[4]D.R. Neuville Cormier, L.,. Montouillout, V.,. Florian, P.,. Millot, F.,. Rifflet, J.C.,. Massiot, D., Structure of $\mathrm{Mg}$ - and $\mathrm{Mg} / \mathrm{Ca}$ aluminosilicate glasses: 27Al NMR and Raman spectroscopy investigations, Am Min. 93 (2008) 1721-1731.

[5]B.E. Yekta, P. Alizadeh, L. Rezazadeh, Synthesis of glass-ceramic glazes in the ZnOA12O3-SiO2-ZrO2 system, J Eur Ceram Soc. 27 (2007) 2311-2315. https://doi.org/10.1016/j.jeurceramsoc.2006.08.009.

[6]M. Leśniak, J. Partyka, M. Sitarz, Impact of $\mathrm{ZnO}$ on the structure of aluminosilicate glazes, J. Mol. Struct. 1126 (2016) 251-258. https://doi.org/10.1016/j.molstruc.2016.01.009.

[7]A. Escardino, J.L. Amorós, A. Gozalbo, M.J. Orts, A. Moreno, Gahnite Devitrification in Ceramic Frits: Mechanism and Process Kinetics, J. Am. Ceram. Soc. 83 (2000) 2938-2944. https://doi.org/10.1111/j.1151-2916.2000.tb01664.x.

[8]A. Wajda, M. Sitarz, Structural and microstructural studies of zinc-doped glasses from NaCaPO4-SiO2 system, J. Non-Cryst. Solids. $441 \quad$ (2016) 66-73. https://doi.org/10.1016/j.jnoncrysol.2016.03.013.

[9]D. Ehrt, S. Flügel, Properties of Zinc Silicate Glasses and Melts, J. Mater. Sci. Eng. A. 1 (2011) 312-320.

[10] D. Ehrt, H.T. Vu, A. Herrmann, G. Völksch, Luminescent ZnO-Al2O3-SiO2 Glasses and Glass Ceramics, Adv. Mater. Res. 39-40 (2008) 228-233.

[11] S. Yoo, U.-C. Paek, W.-T. Han, Development of a glass optical fiber containing ZnOAl2O3-SiO2 glass-ceramics doped with $\mathrm{Co} 2+$ and its optical absorption characteristics, J. Non-Cryst. Solids. 315 (2003) 180-186. https://doi.org/10.1016/S0022-3093(02)01425-4.

[12] S. Zhou, J. Hao, J. Qiu, Ultra-Broadband Near-Infrared Luminescence of Ni2+: ZnOAl2O3-SiO2 Nanocomposite Glasses Prepared by Sol-Gel Method, J. Am. Ceram. Soc. 94 (2011) 2902-2905. https://doi.org/10.1111/j.1551-2916.2011.04671.x.

[13] B. Wu, J. Qiu, M. Peng, J. Ren, X. Jiang, C. Zhu, Transparent Ni2+-doped ZnO-A12O3$\mathrm{SiO} 2$ system glass-ceramics with broadband infrared luminescence, Mater Res Bull. 42 (2007) 762-768. https://doi.org/10.1016/j.materresbull.2006.07.012.

[14] A. Dugué, O. Dymshits, L. Cormier, B. Cochain, G. Lelong, S. Belin, A. Zhilin, 
Structural evolution of Ni environment in lithium, magnesium and zinc aluminosilicate glasses and glass-ceramics, J Non-Cryst Solids. 413 (2015) 24-33. https://doi.org/10.1016/j.jnoncrysol.2015.01.011.

[15] P.W. McMillan, Glass-ceramics, Academic Press, London \& New York, 1964.

[16] G. Della Mea, A. Gasparotto, M. Bettinelli, A. Montenero, R. Scaglioni, Chemical durability of zinc-containing glasses, J. Non-Cryst. Solids. 84 (1986) 443-451. https://doi.org/10.1016/0022-3093(86)90808-2.

[17] H. Scholze, Le verre - Nature, structure et propriétés, Institut du verre, Paris, 1980.

[18] S. Petrescu, M. Constantinescu, E.M. Anghel, I. Atkinson, M. Olteanu, M. Zaharescu, Structural and physico-chemical characterization of some soda lime zinc alumino-silicate glasses, J. Non-Cryst. Solids. $358 \quad$ (2012) 3280-3288. https://doi.org/10.1016/j.jnoncrysol.2012.09.001.

[19] T. Dumas, J. Petiau, EXAFS study of titanium and zinc environments during nucleation in a cordierite glass, J. Non-Cryst. Solids. 81 (1986) 201-220. https://doi.org/10.1016/00223093(86)90270-X.

[20] M. Le Grand Ramos, A.Y.,. Calas, G.,. Galoisy, L.,. Ghaleb, D.,. Pacaud, F., Zinc environment in aluminoborosilicate glasses by Zn K-ege extended x-ray absorption fine structure spectroscopy, J Mater Res. 15 (2000) 2015-2019.

[21] A. Musinu, G. Piccaluga, M. Magini, Coordination of Zinc(II) in ZnO-K2O-SiO2 Glasses by X-ray Diffraction, J. Am. Ceram. Soc. 71 (1988) C-256-C-259. https://doi.org/10.1111/j.1151-2916.1988.tb05073.x.

[22] G. Calas Cormier, L.,. Galoisy, L.,. Jollivet, P., Structure-property relationships in multicomponent oxide glasses, C R Chim. 5 (2002) 831-843.

[23] T. Alizadeh, F. Soleimani, Preparation of nano-glass ceramic in ZAS system without added nucleating agents, J. Non-Cryst. Solids. $520 \quad$ (2019) 119465. https://doi.org/10.1016/j.jnoncrysol.2019.119465.

[24] P. Yaowakulpattana, T. Wakasugi, S. Kondo, K. Kadono, Effect of Alkaline and Alkaline-Earth Metal Oxides Addition on the Glass Formation and Crystallization of ZnOA12O3-SiO2 Glasses, Eng. J. 19 (2015) 21-34. https://doi.org/10.4186/ej.2015.19.3.21.

[25] M.H. Mohd Zaid, K. Amin Matori, S.Hj. Abdul Aziz, H.M. Kamari, W.M. Mat Yunus, Z. Abdul Wahab, N.F. Samsudin, Fabrication and Crystallization of ZnO-SLS Glass Derived Willemite Glass-Ceramics as a Potential Material for Optics Applications, J. Spectrosc. 2016 (2016) 1-7. https://doi.org/10.1155/2016/8084301.

[26] A. Tarafder, A.R. Molla, C. Dey, B. Karmakar, Thermal, Structural, and Enhanced Photoluminescence Properties of Eu3+-doped Transparent Willemite Glass-Ceramic Nanocomposites, J. Am. Ceram. Soc. $96 \quad$ (2013) 2424-2431. https://doi.org/10.1111/jace.12430.

[27] I.P. Alekseeva, O.S. Dymshits, A.A. Zhilin, S.S. Zapalova, D.V. Shemchuk, Transparent glass-ceramics based on $\mathrm{ZnO}$ and $\mathrm{ZnO}: \mathrm{Co} 2+$ nanocrystals, J. Opt. Technol. 81 (2014) 723. https://doi.org/10.1364/JOT.81.000723.

[28] O. Dymshits, M. Shepilov, A. Zhilin, Transparent glass-ceramics for optical applications, MRS Bull. 42 (2017) 200-205. https://doi.org/10.1557/mrs.2017.29.

[29] L. Cormier, S. Zhou, Transition metals as optically active dopants in glass-ceramics, Appl. Phys. Lett. 116 (2020) 260503. https://doi.org/10.1063/5.0014618.

[30] E.N. Buntig, Phase equilibria in the system SiO2-ZnO-A12O3, J Res Nat Bur Stand. 4 (1930).

[31] R. Hansson, B. Zhao, P.C. Hayes, E. Jak, A reinvestigation of phase equilibria in the system A12O3-SiO2-ZnO, Metall. Mater. Trans. B. 36 (2005) 187-193. https://doi.org/10.1007/s11663-005-0019-y.

[32] D. Massiot, F. Fayon, M. Capron, I. King, S. Le Calve, B. Alonso, J.O. Durand, B. 
Bujoli, Z.H. Gan, G. Hoatson, Modelling one- and two-dimensional solid-state NMR spectra, Mag Res Chem. 40 (2002) 70-76.

[33] G.J. Cuello, J. Darpentigny, L. Hennet, L. Cormier, J. Dupont, B. Homatter, B. Beuneu, 7C2, the new neutron diffractometer for liquids and disordered materials at LLB, J. Phys. Conf. Ser. 746 (2016) 012020. https://doi.org/10.1088/1742-6596/746/1/012020.

[34] P. Juhás, T. Davis, C.L. Farrow, S.J.L. Billinge, PDFgetX3 : a rapid and highly automatable program for processing powder diffraction data into total scattering pair distribution functions, J. Appl. Crystallogr. $46 \quad$ (2013) 560-566. https://doi.org/10.1107/S0021889813005190.

[35] W. Smith, T.R. Forester, DL_POLY_2.0: A general-purpose parallel molecular dynamics simulation package, J. Mol. Graph. 14 (1996) 136-141.

[36] A. Pedone, G. Malavasi, M.C. Menziani, A.N. Cormack, U. Segre, A new selfconsistent empirical interatomic potential model for oxides, silicates, and silica-based glasses, J. Phys. Chem. B. 110 (2006) 11780-11795. https://doi.org/10.1021/jp0611018.

[37] O. Dargaud, L. Cormier, N. Menguy, G. Patriarche, Multi-scale structuration of glasses: Observations of phase separation and nanoscale heterogeneities in glasses by Z-contrast scanning electron transmission microscopy, J Non-Cryst Solids. 358 (2012) 1257-1262. https://doi.org/10.1016/j.jnoncrysol.2012.02.026.

[38] L. Martel, M. Allix, F. Millot, V. Sarou-Kanian, E. Véron, S. Ory, D. Massiot, M. Deschamps, Controlling the Size of Nanodomains in Calcium Aluminosilicate Glasses, J. Phys. Chem. C. 115 (2011) 18935-18945. https://doi.org/10.1021/jp200824m.

[39] L. Jiazhi, S. Ying, H. Guanging, An investigation of relationship between phase separation and crystallization of ZnO-Al2O3-SiO2 glasses, J. Phys. Colloq. 43 (1982) C9231-C9-234. https://doi.org/10.1051/jphyscol:1982941.

[40] G. Lusvardi, G. Malavasi, L. Menabue, M.C. Menziani, Synthesis, Characterization, and Molecular Dynamics Simulation Of $\mathrm{Na}_{2} \mathrm{O}-\mathrm{CaO}-\mathrm{SiO}_{2}-\mathrm{ZnO}$ Glasses, J. Phys. Chem. B. 106 (2002) 9753-9760. https://doi.org/10.1021/jp020321s.

[41] L. Cormier, D.R. Neuville, G. Calas, Relationship Between Structure and Glass Transition Temperature in Low-silica Calcium Aluminosilicate Glasses: the Origin of the Anomaly at Low Silica Content: Structure and Glass Transition Temperature Relationship, J. Am. Ceram. Soc. 88 (2005) 2292-2299. https://doi.org/10.1111/j.15512916.2005.00428.x.

[42] S. Takahashi, D.R. Neuville, H. Takebe, Thermal properties, density and structure of percalcic and peraluminus $\mathrm{CaO}-\mathrm{A} 12 \mathrm{O} 3-\mathrm{SiO} 2$ glasses, J. Non-Cryst. Solids. 411 (2015) 512. https://doi.org/10.1016/j.jnoncrysol.2014.12.019.

[43] A. Novikov, Structure and dynamics of aluminosilicate glasses and melts, $\mathrm{PhD}$ Thesis, Université d'Orléans, 2017.

[44] M.J. Buerger, The stuffed derivatives of the silica structures, Am Min. 39 (1954) 600614.

[45] E. Tkalcec, S. Kurajica, H. Ivankovic, Crystallization behavior and microstructure of powdered and bulk ZnO-Al2O3-SiO2 glass-ceramics, J Non Cryst Solids. 351 (2005) 149157. https://doi.org/10.1016/j.jnoncrysol.2004.09.024.

[46] D.R. Neuville, L. Cormier, V. Montouillout, D. Massiot, Local Al site distribution in aluminosilicate glasses by 27Al MQMAS NMR, J. Non-Cryst. Solids. 353 (2007) 180-184. https://doi.org/10.1016/j.jnoncrysol.2006.09.035.

[47] D.R. Neuville Cormier, L.,. Flank, A.M.,. Briois, V.,. Massiot, D., Al speciation and Ca environment in calcium aluminosilicate glasses and crystals by $\mathrm{Al}$ and $\mathrm{Ca} \mathrm{K}$-edge $\mathrm{X}$-ray absorption spectroscopy, Chem Geol. 213 (2004) 153-163.

[48] M.M. Smedskjaer, R.E. Youngman, J.C. Mauro, Impact of $\mathrm{ZnO}$ on the structure and properties of sodium aluminosilicate glasses: Comparison with alkaline earth oxides, J. Non- 
Cryst. Solids. 381 (2013) 58-64. https://doi.org/10.1016/j.jnoncrysol.2013.09.019.

[49] S. Nie, R.M. Thomsen, J. Skibsted, Impact of Mg substitution on the structure and pozzolanic reactivity of calcium aluminosilicate $(\mathrm{CaO}-\mathrm{Al} 2 \mathrm{O} 3-\mathrm{SiO} 2)$ glasses, Cem. Concr. Res. 138 (2020) 106231. https://doi.org/10.1016/j.cemconres.2020.106231.

[50] Q. Zheng, M.M. Smedskjaer, R.E. Youngman, M. Potuzak, J.C. Mauro, Y. Yue, Influence of aluminum speciation on the stability of aluminosilicate glasses against crystallization, Appl Phys Lett. 101 (2012) 041906-4.

[51] P. Richet, M. Roskosz, J. Roux, Glass formation in silicates: insights from composition, Chem Geol. 225 (2006) 388-401.

[52] A.N. Novikov, D.R. Neuville, L. Hennet, Y. Gueguen, D. Thiaudière, T. Charpentier, P. Florian, Al and Sr environment in tectosilicate glasses and melts: Viscosity, Raman and NMR investigation, Chem. Geol. 461 (2017) 115-127. https://doi.org/10.1016/j.chemgeo.2016.11.023.

[53] M.C. Wilding, C.J. Benmore, J.A. Tangeman, S. Sampath, Coordination changes in magnesium silicate glasses, Europhys. Lett. $67 \quad$ (2004) 212-218. https://doi.org/10.1209/epl/i2003-10286-8.

[54] M.C. Wilding, C.J. Benmore, J.A. Tangeman, S. Sampath, Evidence of different structures in magnesium silicate liquids: coordination changes in forsterite- to enstatitecomposition glasses, Chem. Geol. 213 (2004) 281-291.

[55] J.F. Stebbins, I. Farnan, Effects of High Temperature on Silicate Liquid Structure: A Multinuclear NMR Study, Science. $255 \quad$ (1992) 586-589. https://doi.org/10.1126/science.255.5044.586.

[56] J.R. Allwardt, B.T. Poe, J.F. Stebbins, The effect of fictive temperature on Al coordination in high pressure (10 GPa) sodium aluminosilicate glasses, Am Miner. 90 (2005) 1453-1457.

[57] J.R. Allwardt, J.F. Stebbins, B.C. Schmidt, D.J. Frost, A.C. Withers, M.M. Hirschmann, Aluminum coordination and the densification of high-pressure aluminosilicate glasses, Am Miner. 90 (2005) 1218-1222.

[58] P. Florian Sadiki, N.,. Massiot, D.,. Coutures, J.P., 27Al NMR study of the structure of lanthanum- and yttrium-based aluminosilicate glasses and melts, J Phys Chem B. 111 (2007) 9747-9757.

[59] L. Cormier, D.R. Neuville, G. Calas, Structure and properties of low-silica calcium aluminosilicate glasses, J. Non-Cryst. Solids. 274 (2000) 110-114. https://doi.org/10.1016/S0022-3093(00)00209-X.

[60] G. Calas, L. Galoisy, L. Cormier, G. Ferlat, G. Lelong, The Structural Properties of Cations in Nuclear Glasses, Procedia Mater. Sci. 7 (2014) 23-31. https://doi.org/10.1016/j.mspro.2014.10.005.

[61] L. Cormier, G.J. Cuello, Mg coordination in a MgSiO3 glass using neutron diffraction coupled with isotopic substitution, Phys Rev B. $83 \quad$ (2011) 224204. https://doi.org/10.1103/PhysRevB.83.224204.

[62] Q.J. Zheng, R.E. Youngman, C.L. Hogue, J.C. Mauro, M. Potuzak, M.M. Smedskjaer, Y.Z. Yue, Structure of boroaluminosilicate glasses: Impact of [A12O3]/[SiO2] ratio on the structural role of sodium, Phys Rev B. 86 (2012) 054203.

[63] I. Farnan, J.F. Stebbins, The nature of the glass transition in a silica-rich oxide melt, Science. 265 (1994) 1206-1208.

[64] K.-H. Klaska Eck, J.C.,. Pohl, D., New investigation of willemite, Acta Cryst. B34 (1978) 3324-3325.

[65] A.B. Rosenthal, S.H. Garofalini, Structural Role of Zinc Oxide in Silica and Soda-Silica Glasses, J. Am. Ceram. Soc. 70 (1987) 821-826. https://doi.org/10.1111/j.11512916.1987.tb05634.x. 
[66] L. Galoisy Calas, G., Structural environment of nickel in silicate glass / melt systems: Part 2 Geochemical implications, Geochem. Cosmochim. Acta. 57 (1993) 3627-3633.

[67] A. Navrotsky Peraudeau, G.,. McMillan, P.F.,. Coutures, J.P., A thermochemical study of glasses and crystals along the joins silica-calcium aluminate and silica-sodium aluminate, Geochim Cosmochim Acta. 46 (1982) 2039-2047.

[68] B.R. Roy Navrotsky, A., Thermochemistry of charge-coupled substitutions in silicate glasses: the systems M1/nn+AlO2-SiO2 (M=Li, Na, K, Rb, Cs, Mg, Ca, Sr, Ba, Pb), J Amer Ceram Soc. 67 (1984) 606-610. 